\title{
Interdisciplinary GoR level III Guidelines for the Diagnosis, Therapy and Follow-up Care of Breast Cancer Short version - AWMF Registry No.: 032-045OL
}

\author{
Interdisziplinäre S3-Leitlinie für die Diagnostik, Therapie und Nachsorge \\ des Mammakarzinoms
}

AWMF-Register-Nummer: 032-045OL - Kurzversion 3.0, Juli 2012

Authors

Affiliations
R. Kreienberg ${ }^{1}$, U.-S. Albert ${ }^{2}$, M. Follmann ${ }^{3}$, I. B. Kopp ${ }^{4}$, T. Kühn ${ }^{5}$, A. Wöckel ${ }^{6}$

The affiliations are listed at the end of the article.

\section{Bibliography}

Dol http://dx.doi.org/

10.1055/s-0032-1328689

Geburtsh Frauenheilk 2013; 73 :

556-583 @ Georg Thieme

Verlag KG Stuttgart · New York.

ISSN 0016-5751

\section{Correspondence}

Prof. Dr. Achim Wöckel

Universitätsklinikum Ulm

Klinik für Frauenheilkunde

und Geburtshilfe

Prittwitzstraße 43

89075 Ulm

achim.woeckel@

uniklinik-ulm.de
Information about this Guideline

\subsection{Editor}

Guideline Program in Oncology of the AWMF (Association of the Scientific Medical Societies of Germany), the German Cancer Society (Deutsche Krebsgesellschaft e.V.) and German Cancer Aid (Deutsche Krebshilfe e.V.)

\subsection{Funding of this guideline}

These guidelines were funded by the German Cancer Aid (Deutsche Krebshilfe e.V.) within the scope of the Guideline Program in Oncology of the AWMW (Association of Medical Scientific Societies).

\subsection{Lead professional associations}

German Cancer Society (DKG)

German Society of Obstetrics and Gynecology (DGGG)

\subsection{Contact}

Guideline Program in Oncology Office

c/o German Cancer Society

Kuno-Fischer-Straße 8

14057 Berlin

leitlinienprogramm@krebsgesellschaft.de

www.leitlinienprogramm-onkologie.de

\subsection{Additional documents relating to these guidelines}

The topics of this version are the same as in the long version of the S3 Guidelines for the Diagnosis, Treatment and Follow-up Care of Breast Cancer which can be accessed via the links listed below:
- http://www.leitlinienprogramm-onkologie.de/ OL/leitlinien.html

- http://www.awmf.org/leitlinien/aktuelleleitlinien.html

- http://www.krebsgesellschaft.de/wub_ llevidenzbasiert,120884.html

- http://www.krebshilfe.de

- http://www.dggg.de

- http://www.senologie.org

In addition to this short version, the following supplementary documents are available:

- Comprehensive version

- Guideline report

- Patient guide on the early detection of breast cancer

- Patient guide on breast cancer 1: Initial disease and DCIS - A guide for patients

- Patient guide on breast cancer 2: Advanced disease, recurrence and metastasis

- Gartlehner G et al. Comparative efficacy and safety of sentinel lymph node biopsy alone or complete axillary dissection for sentinel-positive breast cancer: A systematic review. 2011

- Agency for Quality in Medicine (ÄZQ). Synopsis of evidence-based guideline recommendations for diagnosis, therapy and follow-up care of breast cancer. Berlin: 2011

- A guideline app called "Leitlinien Onkologie" (in German) can be downloaded at http:// itunes.apple.com/de/app/leitlinien-onkologie/ id453786520?mt=8 or https://play.google.com/ store/apps/details?id $=$ de.dkg.app\&feature $=$ apps_topselling_free\#?

t=W251 bGwsMSwyLG51 bGwsImRILmRrZy 5hcHAiXQ. The contents of these guidelines are anticipated to be published this year. 


\subsection{Responsibilities}

1.6.1 Authors of these guidelines

\section{Steering group}

\begin{tabular}{|l|l|}
\hline Name & Town/city \\
\hline Prof. Rolf Kreienberg, M. D. & Ulm \\
\hline Prof. Ute-Susann Albert, M. D. & Marburg \\
\hline Dr. Markus Follmann, MPH MSc. & Berlin \\
\hline Prof. Ina Kopp, M. D. & Marburg \\
\hline Prof. Thorsten Kühn, M. D. & Esslingen \\
\hline Dr. Achim Wöckel, M. D., External Lecturer & Ulm \\
\hline Thomas Zemmler, Economic Mathematician & Ulm \\
\hline
\end{tabular}

Editorial Support: A. Hellberg, Ulm

\section{Experts}

\section{Name}

Prof. Matthias W. Beckmann, M. D.

Town/city

Prof. Andreas Buck, M. D.

Prof. Jutta Engel, M. D.

Anita Feller

Prof. Max Geraedts, M. D.

Andrea Hahne

Prof. Sylvia Heywang-Köbrunner, M. D.

Prof. Christian Jackisch, M. D.

Dr. Monika Klinkhammer-Schalke

Prof. Nicolai Maass, M. D.

Prof. Alfons Meindl, D.Sc.

Prof. Volker Möbus, M. D.

Karen Pottkämper

Kerstin Rhiem, PD Dr.

Prof. Andreas Schneeweiss, M. D.

Prof. Ingrid Schreer, M. D.

Dr. Nicole Skoetz

Prof. Michael Untch, M. D.

Prof. Gunter von Minckwitz, M. D.

Prof. Uwe Wagner, M.D.
Erlangen

Würzburg

Munich

Göttingen

Witten

Bad Münder

Munich

Offenbach

Berlin

Aachen

Munich

Frankfurt

Göttingen

Cologne

Heidelberg

Kiel

Cologne

Berlin

Neu-Isenburg

Marburg

\section{Representatives of professional associations}

\section{Name}

\section{Professional association}

Working Group of German Tumor Centers (ADT)

Working Group on Psychooncology (PSO)

Working Group on Ultrasound Diagnosis in Obstetrics and Gynecology (ARGUS)

Working Group on Gynecological Oncology (AGO)

Working Group on Medical Oncology (AIO)

Working Group on Radiological Oncology (ARO)

Working Group on Supportive Measures in Oncology, Rehabilitation and Social Medicine (ASORS)

Working Group on Prevention and Integrative Medicine in Oncology (PRiO)

Professional Association of Gynecologists

BQS [Federal Office of Quality Assurance] Institute for Quality and Patient Safety German Professional Association of Pathologists

Working Group on Surgical Oncology (CAO-V)

German Society for General and Family Medicine (DEGAM)

German Society of Obstetrics and Gynecology (DGGG)

German Society of Hematology and Oncology (DGHO)

German Society of Palliative Care Medicine (DGP)

German Society of Pathology (DGP)

German Society for Radiooncology (DEGRO)

German Society of Rehabilitation Sciences (DGRW)

German Society of Senology (DGS)

German Society for Ultrasound in Medicine (DEGUM)

German Radiological Society (DRG)

German Association for Physiotherapy, Central Association of Physiotherapists

(ZVK)

Consortium for Hereditary Breast and Ovarian Cancer

Women's Self-Help after Cancer

Society of Plastic, Reconstructive and Esthetic Surgery (DGPRÄC)

Conference of Oncology and Pediatric Nursing (KOK)

Munich Tumor Registry (TRM)

Women's Health Coalition (WHC)
Prof. Dieter Hölzel, M.D.

Prof. Joachim Weis, M.D.

Prof. Helmut Madjar, M. D.

Prof. Jens Blohmer, M.D.

Prof. Anton Scharl, M. D.

Dr. Norbert Marschner

Prof. Jürgen Dunst, M. D.

Prof. Rainer Souchon, M. D.

Prof. Hans Helge Bartsch, M. D.

Prof. Günter Emons, M. D.

Prof. Hartmut Link, M.D.

Dr. Jutta Hübner

Dr. Klaus König

Dr. Sven Bungard

Prof. Werner Schlake, M. D.

Prof. Martin Angele, M.D.

Prof. Erika Baum, M. D.

Dr. Brigitte Ernst

Prof. Bernd Gerber, M. D.

Prof. Nadia Harbeck, M. D.

Prof. Kurt Possinger, M. D.

Dr. Jan Gärtner

Dr. Christina Gerlach

Prof. Manfred Dietel, M. D.

Prof. Hans Kreipe, M. D.

Dr. Annette Lebeau, external lecturer

Prof. Wilfried Budach, M.D.

Prof. Hans Helge Bartsch, M. D.

Dr. Kerstin Knauth

Prof. Wolfgang Janni, M. D.

Prof. Christoph Thomssen, M. D.

Prof. Friedrich Degenhardt, M. D.

Prof. Ulrich Bick, M. D.

Ulla Henscher

Hannelore Ruppert

Prof. Rita Schmutzler, M. D.

Hilde Schulte

Prof. Christoph Heitmann, M. D.

Dr. Mario Marx

Kerstin Paradies

Prof. Jutta Engel, M. D.

Irmgard Naß-Griegoleit

\begin{tabular}{l} 
Town/city \\
Munich \\
\hline Freiburg \\
\hline Wiesbaden \\
Berlin \\
Amberg \\
\hline Freiburg \\
\hline Lübeck \\
Tübingen \\
\hline Freiburg \\
Göttingen \\
Kaiserslautern \\
\hline Frankfurt \\
\hline Steinbach \\
\hline Düsseldorf \\
\hline Gelsenkirchen \\
\hline Munich \\
\hline Marburg \\
Regensburg \\
\hline Rostock \\
\hline Munich \\
\hline Berlin \\
\hline Cologne \\
Mainz \\
\hline Berlin \\
Hannover \\
Lübeck, Hamburg \\
\hline Düsseldorf \\
\hline Freiburg \\
Ratzeburg \\
\hline Ulm \\
Halle \\
\hline Bielefeld \\
\hline Berlin \\
\hline Hannover \\
Cologne \\
Cologne \\
\hline Neukirchen \\
Munich \\
Radebeul \\
\hline Hamburg \\
\hline Munich \\
\hline Darmstadt \\
\hline
\end{tabular}




\subsubsection{Group leaders, working parties and reviewers}

\section{Chapters/topical emphasis}

Chapter 3 General

\subsection{Patient information and education \\ 3.2 Early detection, mammographic screening \\ 3.3 Women at increased risk of developing breast cancer}

Chapter $\mathbf{4}$ Locoregional primary disease

\begin{tabular}{|ll}
\hline 4.1 & General diagnostic and therapeutic concepts \\
\hline 4.2 & $\begin{array}{l}\text { Pretherapeutic diagnosis in patients with abnormal } \\
\text { or suspicious breast findings }\end{array}$ \\
\hline 4.3 & Preinvasive neoplasms
\end{tabular}

\subsection{Surgical treatment of invasive carcinoma}

4.5 Pathomorphological study

4.6 Adjuvant radiotherapy of breast cancer

4.7 Systemic adjuvant therapy (endocrine therapy, chemotherapy and antibody therapy)

4.7.1 Choice of adjuvant therapy and risk assessment

4.7.2 Endocrine therapy

4.7.3 Chemotherapy

4.7.4 Neoadjuvant (primary systemic) therapy (NACT or PST)

4.7.5 Antibody therapy

4.7.6 Bisphosphonates

4.8 Management of primary local or locoregional advanced tumors

\section{Chapter 5 Recurrent or metastatic breast cancer}

\begin{tabular}{ll}
5.1 & Definition and prognosis \\
\hline 5.2 & Diagnostic procedures for local or locoregional recurrence \\
\hline 5.3 & Treatment of local/locoregional recurrence \\
\hline
\end{tabular}

\section{Chapter 6 Treatment, care and support}

\begin{tabular}{|ll}
\hline 6.1 & Ceneral concept \\
\hline 6.2 & Psychosocial aspects and psycho-oncology \\
\hline 6.3 & Supportive therapy \\
\hline 6.4 & $\begin{array}{l}\text { Fehabilitation } \\
\text { metastases and support during therapy }\end{array}$ \\
\hline 6.5 & Palliative medicine \\
\hline 6.7 & Complementary therapy \\
\hline 6.8 & Documentation \\
\hline
\end{tabular}

Chapter 7 Care coordination and quality management
Spokespersons, (reviewers), working group

Albert, (Wöckel), Ernst, König, Kreienberg, Naß-Griegoleit, Schulte, Weis Schreer, (Albert), Baum, Bick, Degenhardt, Engel, Heywang-Köbrunner, Hölzel, König, Madjar, Schmutzler

Schmutzler, (Bick), Albert, Hahne, Lebeau, Madjar, Meindl, Rhiem, Schreer

\section{Steering group}

Kühn, (Albert), Bick, Degenhardt, Kreienberg, Kreipe, Lebeau, Madjar, Schreer

Kreipe/Beckmann, (Lebeau/Dietel), Albert, Harbeck, Kühn, Marx, Schlake, Schreer, Souchon

Blohmer, (Kühn), Angele, Budach, Dietel, Engel, Kreienberg, Lebeau, Marx, Scharl, Souchon, Wagner

Lebeau, (Kreipe/Dietel), Harbeck, Janni, Schlake, Thomssen Souchon/Dunst, (Thomssen), Blohmer, Budach, Hölzel, Kühn, Untch

Kreienberg, Gerber, Harbeck, Possinger, Thomssen

Possinger, (Maass), Emons, Scharl

Harbeck, (Möbus), Janni, Possinger

Gerber, (v. Minckwitz), Marschner, Untch

Thomssen, (Schneeweiss), Jackisch

Thomssen, (Schneeweiss), Jackisch

Steering group

\section{Steering group}

Bick, (Scharl), Blohmer, Buck, Degenhardt, Madjar

Dunst, (Kühn), Angele, Blohmer, Dietel, Heitmann, Marx, Gerber

Marschner, (Emons), Angele, Dunst, Harbeck, Possinger, Thomssen

\section{Steering group}

Weis/Beckmann, (Scharl), Albert, Bartsch, Ernst, Faller, König, Naß-Griegoleit, Schulte

Link, (Follmann), Baum, Emons, Henscher, Ruppert, Skoetz

Bartsch, (Schulte), Baum, Henscher, Knauth, Ruppert

Janni, (Beckmann), Hölzel, König, Naß-Griegoleit, Paradies, Schulte, Souchon, Thomssen, Weis

Gärtner, (Schulte), Beckmann, Gerlach, Naß-Griegoleit

Hübner, Naß-Grigoleit, Schulte, Albert, Wöckel

Engel, Hölzel, Klinkhammer-Schalke, Pottkämper

Wagner, (Kopp), Albert, Beckmann, Bungard, Engel, Ernst, Follmann, Geraedts, Hölzel, Klinkhammer-Schalke, Lebeau, Souchon, Thomssen, Pottkaemper, Feller, Wesselmann, Wöckel

\subsubsection{Consulting}

1. Leitlinienprogramm Onkologie

- Prof. Dr. Ina Kopp, Marburg (AWMF)

- Dr. Markus Follmann, MPH MSc, Berlin (DKG)

2. External partner:

- Ärztliches Zentrum fur Qualität in der Medizin (ÄZQ), Berlin

- Donau-Universität Krems, Department fur Evidenzbasierte Medizin und

- Klinische Epidemiologie

- Deutsches Cochrane Zentrum, Cochrane Haematological Malignancies Group

3. Medical society:

- Deutsche Krebsgesellschaft e.V. (DKG)

- Deutsche Gesellschaft fur Gynakologie und Geburtshilfe (DGGG) 


\subsection{Abbreviations used}

\begin{tabular}{|c|c|}
\hline Abbreviation & Explanation \\
\hline ACR & American College of Radiology \\
\hline ADH & Atypical (intra-)ductal hyperplasia \\
\hline $\mathrm{Al}$ & Aromatase inhibitor \\
\hline APBI & Accelerated partial breast irradiation \\
\hline ASCO & American Society of Clinical Oncology \\
\hline BCT & Breast-conserving therapy \\
\hline BI-RADS & Breast imaging reporting and data system \\
\hline CAD & Computer-aided detection \\
\hline CAP & College of American Pathologists \\
\hline $\mathrm{CISH}$ & Chromogenic in-situ hybridization \\
\hline DCIS & Ductal carcinoma in situ \\
\hline DFS & Disease-free survival \\
\hline DGS & $\begin{array}{l}\text { Deutsche Gesellschaft für Senologie - German Society } \\
\text { of Senology }\end{array}$ \\
\hline DKG & Deutsche Krebsgesellschaft - German Cancer Society \\
\hline EBM & Evidence-based medicine \\
\hline EORTC & $\begin{array}{l}\text { European Organisation for Research and Treatment of } \\
\text { Cancer }\end{array}$ \\
\hline $\mathrm{FISH}$ & Fluorescence in-situ hybridization \\
\hline FN & Febrile neutropenia \\
\hline HER2 & Human epidermal growth factor receptor 2 \\
\hline ITC & Isolated tumor cells \\
\hline IORT & Intraoperative radiotherapy \\
\hline CE-MRI & Contrast-enhanced magnetic resonance imaging \\
\hline LCIS & Lobular carcinoma in situ \\
\hline LIN & Lobular intraepithelial neoplasia \\
\hline LOE & Level of evidence \\
\hline MRM & Modified radical mastectomy \\
\hline MRI & Magnetic resonance imaging \\
\hline NACT & Neoadjuvant chemotherapy \\
\hline NCCN & National Comprehensive Cancer Network \\
\hline NHSBSP & $\begin{array}{l}\text { National Coordinating Group for Breast Screening } \\
\text { Pathology }\end{array}$ \\
\hline NICE & National Institute for Health and Clinical Excellence \\
\hline NOS & Not otherwise specified \\
\hline NZGG & New Zealand Guidelines Group \\
\hline OS & Overall survival \\
\hline $\mathrm{PBI}$ & Partial breast irradiation \\
\hline $\mathrm{PCR}$ & Pathological complete remission \\
\hline PCR & polymerase chain reaction \\
\hline SLNB & Sentinel lymph node biopsy \\
\hline RT & Radiotherapy \\
\hline UDH & Intraductal hyperplasia \\
\hline UICC & Union internationale contre le cancer \\
\hline WHO & World Health Organization \\
\hline
\end{tabular}

$2 \quad$ Notices

\subsection{Special notice}

Health care is in a continous process of evolution, so that all information, particularly about diagnostic and therapeutic procedures, is only as good as the state of knowledge at the time the guidelines are printed. The greatest possible care has been taken over the recommendations given for treatment and the choice and dosage of medications. Nevertheless, users are asked to consider the manufacturer's package leaflet and summary of product characteristics and consult a specialist in case of any doubt. In our general interest, please notify the GGPO editors of any inconsistencies or discrepancies you may find.

The user remains personally liable for all diagnostic and therapeutic applications, medications and dosages.

Registered trademarks and brand names are not specifically identified in these care guidelines. It therefore cannot be inferred that a trademark is free merely by the lack of any such reference.

This work is protected in whole and in part. Any use that infringes the terms of the law on copyright without written authorization from the GGPO editors is prohibited and a criminal offence. No part of this guideline may be reproduced in any form whatsoever without the written permission of the GGPO editors. This applies in particular to photocopies, translations and microfilms and to storage, use and processing on electronic systems, intranets and the internet. 


\subsection{Patient information and education}

$\begin{array}{ll}\text { Info-1 } & \text { Information material } \\ & \text { The provision of qualified and useful information material } \\ \text { (printed or Internet material) should meet defined quality } \\ \text { criteria for health information and should provide the pa- } \\ \text { tient with easily understood risk information (e.g. specifi- } \\ \text { cation of absolute risk reductions) to help her arrive at a self- } \\ \text { determined decision for or against medical procedures. } \\ \text { (Albert US et al. 2003; Albert US et al. 2008; Klemperer D } \\ \text { et al. 2010) }\end{array}$

\begin{tabular}{|c|c|}
\hline Info-2 & Basic principles of patient-centered communication \\
\hline $\begin{array}{l}\text { Grade of } \\
\text { recommendation } \\
\text { A }\end{array}$ & $\begin{array}{l}\text { When conveying information to the patient, doctors should } \\
\text { observe the following basic principles of patient-centered } \\
\text { communication, allowing the patient to participate in the } \\
\text { decision-making process: } \\
\text { D Display empathy and listen actively } \\
\text { - Address difficult topics directly and with empathy } \\
\text { - Whenever possible, avoid medical terminology, and if } \\
\text { medical terms cannot be avoided, they should be ex- } \\
\text { plained } \\
\text { - Employ strategies that improve understanding (e.g. re- } \\
\text { peating, summarizing the salient points, using graphics, } \\
\text { etc.) } \\
\text { Encourage the patient to ask questions. } \\
\text { - Allow and encourage the expression of feelings. } \\
\text { Offer further assistance (Cf. Psychooncology) }\end{array}$ \\
\hline $\begin{array}{l}\text { Level of } \\
\text { evidence } \\
\text { 1b }\end{array}$ & $\begin{array}{l}\text { (Bruera E et al. 2002; Butow P et al. 2007; Elkin EB et al. } \\
\text { 2007; Ford S et al. 2006; NICE 2009a; Politi MC et al. 2007) }\end{array}$ \\
\hline
\end{tabular}

Info-3

Consultation to inform the patient about treatment

The consultation to inform the patient about the treatment should cover the following points at least:

- Surgical therapy: possibilities for breast-conserving therapy with mandatory radiotherapy as equivalent to mastectomy with different variants of primary and secondary reconstruction or the provision of an external prosthesis

- Systemic therapy: principles and desired treatment targets of adjuvant or palliative therapy, duration and mode of administration of therapy, its side effects and possible late sequelae, and the treatment options for side effects

- Radiotherapy: principles and desired treatment targets, duration and follow-up surveillance, possible acute and late sequelae, treatment options for side effects

- Participation in clinical studies, principles behind the treatment and treatment targets, duration and mode of administration of the therapy, effects and side-effects known to date, special features (e.g. monitoring, additional measures, cooperation, data storage and processing)

- Other: possibilities for prevention and treatment of therapy-related side effects (e.g. emesis, osteoporosis, lymphedema, etc.), necessity for follow-up care, possibilities for rehabilitation and psycho-oncological support as well as services offered by self-help groups, aspects that are the responsibility of the patient and cooperation (e.g. reporting symptoms and problems, treatment compliance)

(NZGG 2009)

\subsection{Early detection, mammographic screening}

\begin{tabular}{|c|c|}
\hline \multirow[t]{2}{*}{ Early-1 } & Early detection \\
\hline & $\begin{array}{l}\text { a. Early breast cancer detection is a cross-sectoral task. } \\
\text { There should be a quality-assured, interdisciplinary } \\
\text { combination of clinical examination, instrument-based } \\
\text { diagnosis, surgical exploration and pathomorphological } \\
\text { evaluation. }\end{array}$ \\
\hline \multirow[t]{2}{*}{ GCP } & (Albert US et al. 2008) \\
\hline & $\begin{array}{l}\text { b. The care chain requires complex and quality-assured } \\
\text { medical documentation to unify the whole quality man- } \\
\text { agement process. }\end{array}$ \\
\hline \multirow[t]{2}{*}{ GCP } & (Albert US et al. 2008) \\
\hline & $\begin{array}{l}\text { c. Cancer registries are as important as they are necessary } \\
\text { for the evaluation and quality assurance of early breast } \\
\text { cancer detection. All patients diagnosed with breast } \\
\text { cancer should therefore be reported to a cancer registry } \\
\text { including the relevant details on primary findings and } \\
\text { primary therapy. Cancer registries contribute to evalua- } \\
\text { tion and quality assurance through population-related } \\
\text { and regionally based analyses of tumor stages and long- } \\
\text { term follow-up (recurrences and survival). When an early } \\
\text { detection program is instituted or adapted, baseline da- } \\
\text { ta should be available for the preceding period. }\end{array}$ \\
\hline \multirow[t]{2}{*}{ GCP } & (Albert US et al. 2008) \\
\hline & $\begin{array}{l}\text { d. Examinations for early detection can cause physical and } \\
\text { mental stress. This situation must be urgently addressed } \\
\text { by careful information and an effective communication } \\
\text { strategy. }\end{array}$ \\
\hline GCP & (Albert US et al. 2008) \\
\hline \multirow[t]{3}{*}{$\begin{array}{l}\text { Grade of recom- } \\
\text { mendation } \\
\text { A }\end{array}$} & $\begin{array}{l}\text { e. In the context of early breast cancer detection, informa- } \\
\text { tion should not just be confined to preformulated texts, } \\
\text { but necessitates an informational discussion with the } \\
\text { doctor that takes account of the woman's preferences, } \\
\text { needs, worries and anxieties and allows joint decision- } \\
\text { making for informed consent. } \\
\text { In the case of mammography screening, information } \\
\text { and explanations should be provided to the woman in } \\
\text { the first place in writing, with the additional mention of } \\
\text { the possibility of a consultation with the doctor in the } \\
\text { invitation letter. }\end{array}$ \\
\hline & (Albert US et al. 2008) \\
\hline & $\begin{array}{l}\text { f. Health outcome and quality of life should be recorded } \\
\text { and evaluated in the long term with particular regard to } \\
\text { any false-positive and false-negative findings in the di- } \\
\text { agnostic chain. }\end{array}$ \\
\hline \multirow[t]{2}{*}{ GCP } & (Albert US et al. 2008) \\
\hline & $\begin{array}{l}\text { g. Women should be offered the possibility of discussing } \\
\text { their medical history and possible risk factors as part of } \\
\text { the statutory early cancer screening. }\end{array}$ \\
\hline GCP & (Albert US et al. 2008) \\
\hline $\begin{array}{l}\text { Grade of recom- } \\
\text { mendation } \\
\text { A }\end{array}$ & $\begin{array}{l}\text { h. The main population-related risk factor for the develop- } \\
\text { ment of breast cancer is advanced age. }\end{array}$ \\
\hline $\begin{array}{l}\text { Level of evidence } \\
2 \mathbf{a}\end{array}$ & (Albert US et al. 2008) \\
\hline $\begin{array}{l}\text { Grade of recom- } \\
\text { mendation } \\
\text { B }\end{array}$ & $\begin{array}{l}\text { i. Next to the BRCA1/2 mutation, high mammographic } \\
\text { density (ARC } 3 \text { and } 4 \text { ) is the greatest individual risk factor, } \\
\text { so that the limited sensitivity of mammography in this } \\
\text { context should be enhanced by an additional ultrasound } \\
\text { scan. }\end{array}$ \\
\hline $\begin{array}{l}\text { Level of evidence } \\
\text { 3b }\end{array}$ & (Albert US et al. 2008) \\
\hline
\end{tabular}




\begin{tabular}{|c|c|}
\hline \multirow[t]{2}{*}{ Early-1 } & Early detection (continuation) \\
\hline & $\begin{array}{l}\text { j. Women aged } 70 \text { years and over can be invited to partic- } \\
\text { ipate in early detection measures, with due regard to the } \\
\text { individual risk profile, health status and life expectancy. }\end{array}$ \\
\hline \multirow[t]{2}{*}{ GCP } & (Albert US et al. 2008) \\
\hline & $\begin{array}{l}\text { k. Women with a BRCA1 or BRCA2 gene mutation, or with a } \\
\text { high risk defined as a heterozygous risk }>20 \% \text { or a per- } \\
\text { manent lifelong risk of developing the disease }>30 \% \text {, } \\
\text { should seek advice in specialist centers for hereditary } \\
\text { breast and ovarian cancer and be counseled about an in- } \\
\text { dividual early detection strategy. }\end{array}$ \\
\hline GCP & (Albert US et al. 2008) \\
\hline $\begin{array}{l}\text { Grade of recom- } \\
\text { mendation } \\
\text { A }\end{array}$ & $\begin{array}{l}\text { I. Quality-assured mammographic screening at 2-year in- } \\
\text { tervals in women aged between } 50 \text { and } 70 \text { years old is } \\
\text { suited for detecting breast cancer early. At present, it is } \\
\text { the only method generally recognized to be effective in } \\
\text { detecting early stages of breast cancer or early tumor } \\
\text { stages. }\end{array}$ \\
\hline $\begin{array}{l}\text { Level of } \\
\text { evidence } \\
\text { 1a }\end{array}$ & (Albert US et al. 2008) \\
\hline $\begin{array}{l}\text { Grade of recom- } \\
\text { mendation } \\
\text { A }\end{array}$ & $\begin{array}{l}\text { m. Self-examination of the breasts, even with regular appli- } \\
\text { cation and training, is not sufficient as a method on its } \\
\text { own for reducing breast cancer mortality. }\end{array}$ \\
\hline \multirow{2}{*}{$\begin{array}{l}\text { Level of evidence } \\
\text { 1a }\end{array}$} & (Albert US et al. 2008) \\
\hline & $\begin{array}{l}\text { n. Women should be encouraged through qualified infor- } \\
\text { mation to familiarize themselves with the normal } \\
\text { changes of their own body. These include the appear- } \\
\text { ance and feel of the breast so that the woman can iden- } \\
\text { tify any abnormalities herself. }\end{array}$ \\
\hline \multirow[t]{2}{*}{ GCP } & (Albert US et al. 2008) \\
\hline & $\begin{array}{l}\text { o. The clinical breast examination, in other words palpa- } \\
\text { tion, breast inspection and evaluation of lymphatic flow, } \\
\text { should be offered annually as part of the statutory early } \\
\text { screening tests for women aged } 30 \text { years and over. }\end{array}$ \\
\hline \multirow[t]{2}{*}{ GCP } & (Albert US et al. 2008) \\
\hline & $\begin{array}{l}\text { p. Ultrasound on its own is not suitable as a method of early } \\
\text { detection. }\end{array}$ \\
\hline GCP & (Albert US et al. 2008) \\
\hline B & $\begin{array}{l}\text { q. CE-MRI should be utilized as a supplementary method in } \\
\text { the presence of a familial increased risk (BRCA1 or BRCA2 } \\
\text { mutation carriers, or with a high risk defined as a heter- } \\
\text { ozygous risk }>20 \% \text { or a permanent lifelong risk of devel- } \\
\text { oping the disease }>30 \% \text { ). }\end{array}$ \\
\hline $\begin{array}{l}\text { Level of evidence } \\
2 a\end{array}$ & (Albert US et al. 2008) \\
\hline
\end{tabular}

\section{Early-2 Mammography}

Grade of recommendation

B

a. A reduction in breast cancer mortality is also documented for women aged between 40 and 49 years and outweighs the risks resulting from radiation exposure. However, the figure is lower in the age group of women between 50 and 69 years, in whom relatively more falsepositive and false-negative findings are obtained. Consequently, the decision should be taken on the basis of an individual risk analysis and a risk-benefit evaluation, as well as with due regard to the woman's preferences and objections.

Level of evidence (Albert US et al. 2008)

$1 \mathrm{~b}$

Grade of recom- b. Second opinions on screening mammograms increase mendation the sensitivity of carcinoma detection by $2.9-13.7 \%$

B (median 7.8\%). Depending on the decision-making process following a second opinion, the specificity may be reduced (up to $2.1 \%$ ) or increased (up to $2.8 \%$ ).

Level of evidence (Albert US et al. 2008)

2b

Grade of recom- c. It is not possible on the basis of the currently available mendation study data to determine unequivocally whether the use 0 of CAD systems can replace second opinions.

Level of evidence (Albert US et al. 2008)

3b

d. The structural, process and outcome quality is regulated for mammography in conjunction with the mammographic screening of women aged between 50 and 69 years.

GCP

(Albert US et al. 2008)

Grade of recom- e. Structural, process and outcome quality should also be mendation

A used to the appropriate extent for so-called curative mammography.

Level of evidence (Albert US et al. 2008)

2b

f. If a mammographic finding of BI-RADSO, III, IV or V is obtained, further investigations should be performed within 5 working days to minimize the mental burden on the woman as far as possible.

GCP (Albert US et al. 2008; Madjar H et al. 2003)

\section{Early-3 Biopsies}

Grade of recom- a. With interventional, and preferably ultrasound-guided, mendation biopsies, > 3 specimens should be taken using a $16 \mathrm{G}$ B needle.

Level of evidence (Albert US et al. 2008)

3b

b. Stereotactic vacuum-assisted biopsy should be performed in a standardized way. The access route and needle positioning (stroke margin) must be documented.

GCP

(Albert US et al. 2008)

Grade of recom-

c. The excision of findings detected only on ultrasound mendation

A should be monitored by intraoperative specimen ultrasound.

Level of evidence (Albert US et al. 2008)

3b 


\subsection{Women at increased risk of developing breast cancer}

\begin{tabular}{|c|c|}
\hline Risk-1 & Counseling and genetic testing \\
\hline & $\begin{array}{l}\text { Multidisciplinary counseling and genetic testing should be } \\
\text { carried out at special centers if one line of the family in- } \\
\text { cludes: } \\
\text { - at least three women who developed breast cancer } \\
\text { at least two women (including one below age } 50 \text { ) who } \\
\text { developed breast cancer } \\
\text { at least one woman who developed breast cancer and } \\
\text { one woman who developed ovarian cancer } \\
\text { at least two women who developed ovarian cancer } \\
\text { at least one woman who developed breast and ovarian } \\
\text { cancer } \\
\text { at least one woman who developed breast cancer before } \\
\text { age } 36 \\
\text { at least one woman who developed cancer in both } \\
\text { breasts before age } 51 \\
\text { at least one man who developed breast cancer and one } \\
\text { woman who developed breast or ovarian cancer. }\end{array}$ \\
\hline
\end{tabular}

$\begin{array}{ll}\text { Risk-2 } & \text { Pathology of BRCA1-associated carcinoma of the } \\ & \text { breast } \\ & \text { a. BRCA1-associated carcinomas of the breast frequently } \\ & \text { exhibit a characteristic histopathological and immuno- } \\ & \text { histochemical phenotype: } \\ & \text { invasive carcinoma (NOS) with a growth pattern similar } \\ & \text { to that of medullary carcinoma } \\ & \text { G3 morphology } \\ & \text { negativity for estrogen receptors, progesterone recep- } \\ & \text { tors and HER2/neu (triple negative) }\end{array}$

\section{Risk-3}

GCP

\section{Intensified early detection}

Early detection measures in patients with a high* familial risk include:

- Palpation of the breast by the doctor (every 6 months; from the age of 25 or 5 years before the earliest age of onset of the disease in the family)

- Ultrasound examination of the breast (every 6 months; from the age of 25 or 5 years before the earliest age of onset of the disease in the family)

- Mammography of the breast (every 12 months; from the age of 30 , for subjects with a high mammary gland density (ACR4) from the age of 35)

- MRI of the breast (every 12 months; from the age of 25 or 5 years before the earliest age of onset of the disease in the family, usually only up to age 55 or until involution of the glandular parenchyma (ACRI-II), cycle-dependently in premenopausal women).

(Consortium of familial breast and ovarian cancer)

* i.e. confirmed pathogenic BRCA1 or BRCA2 mutation, or a permanent risk of developing the disease of $30 \%$ or more, or a heterozygous risk of $20 \%$ or more.

\section{Risk-4 \\ Treatment of BRCA-associated carcinoma of the breast \\ The treatment of BRCA-associated carcinoma of the breast is based on the guideline recommendations for sporadic carcinoma of the breast. \\ GCP}

$\begin{array}{ll}\begin{array}{ll}\text { Risk-5 } \\ \text { Grade of recom- } \\ \text { mendation }\end{array} & \begin{array}{l}\text { Primary prevention } \\ \text { Bomen with pathogenic BRCA1 or BRCA2 should be of- } \\ \text { fered a bilateral prophylactic mastectomy. Bilateral pro- } \\ \text { phylactic salpingo-oophorectomy (usually around the age } \\ \text { of 40) is recommended. }\end{array} \\ \begin{array}{ll}\text { Level of evidence } \\ \text { 3a }\end{array} & \begin{array}{l}\text { (Bermejo-Perez MJ et al. 2007; Calderon-Margalit R et al. } \\ \text { 2010; Domchek SM et al. 2006; Evans DG et al. 2009a; } \\ \text { NZGG 2009) }\end{array}\end{array}$

\section{$4 \quad$ Locoregional Primary Disease}

\subsection{General diagnostic and therapeutic concepts (no statements)}

\subsection{Pretherapeutic diagnosis in patients with abnormal or suspicious breast findings \\ 4.2.1 Basic diagnostic workup}

\begin{tabular}{|c|c|}
\hline Stag-1 & Basic diagnostic workup \\
\hline $\begin{array}{l}\text { Grade of recom- } \\
\text { mendation } \\
\text { A }\end{array}$ & $\begin{array}{l}\text { a. Necessary baseline examinations include: } \\
\text { - clinical breast examination: Breast inspection and palpa- } \\
\text { tion of breast and lymphatic drainage areas } \\
\text { - Mammography } \\
\text { - Ultrasound } \\
\text { If the clinical breast examination produces abnormal find- } \\
\text { ings, diagnostic imaging and histological examination } \\
\text { should be performed to complete the diagnostic workup. }\end{array}$ \\
\hline $\begin{array}{l}\text { Level of evidence } \\
\text { 1a }\end{array}$ & (NICE 2009b; NZGG 2009) \\
\hline $\begin{array}{l}\text { Grade of recom- } \\
\text { mendation } \\
\text { A }\end{array}$ & $\begin{array}{l}\text { b. For the investigation of symptomatic findings in women } \\
\text { under age } 40 \text {, sonography is the imaging method of first } \\
\text { choice. }\end{array}$ \\
\hline $\begin{array}{l}\text { Level of evidence } \\
\mathbf{3 b}\end{array}$ & (Nothacker M et al. 2007) \\
\hline $\begin{array}{l}\text { Grade of recom- } \\
\text { mendation } \\
\text { B }\end{array}$ & $\begin{array}{l}\text { c. The effects of endogenous and exogenous hormones } \\
\text { should be taken into account during the performance } \\
\text { and interpretation of diagnostic procedures. }\end{array}$ \\
\hline $\begin{array}{l}\text { Level of evidence } \\
\mathbf{2 b}\end{array}$ & (Albert US et al. 2008; Houssami N et al. 2009) \\
\hline
\end{tabular}

\subsubsection{Imaging methods}

\begin{tabular}{|c|c|}
\hline Stag-2 & Mammography \\
\hline $\begin{array}{l}\text { Grade of recom- } \\
\text { mendation } \\
\text { A }\end{array}$ & $\begin{array}{l}\text { a. For the investigation of abnormal clinical findings in } \\
\text { women under age } 40 \text {, mammography is the imaging } \\
\text { method of first choice. }\end{array}$ \\
\hline $\begin{array}{l}\text { Level of evidence } \\
\text { 1a }\end{array}$ & (NICE 2009b; NZGG 2009) \\
\hline $\begin{array}{l}\text { Grade of recom- } \\
\text { mendation } \\
\text { A }\end{array}$ & $\begin{array}{l}\text { b. In high mammographic density (ARC3 and 4), the sensi- } \\
\text { tivity of mammography is limited and should be en- } \\
\text { hanced by an additional ultrasound scan. }\end{array}$ \\
\hline $\begin{array}{l}\text { Level of evidence } \\
\text { 3b }\end{array}$ & (Nothacker M et al. 2007; Nothacker M et al. 2009) \\
\hline
\end{tabular}




\begin{tabular}{|c|c|}
\hline Stag-3 & Ultrasonography \\
\hline & $\begin{array}{l}\text { a. Sonography is a supplementary study performed to in- } \\
\text { vestigate indeterminate lesions. (clinical/mammo- } \\
\text { graphic). }\end{array}$ \\
\hline $\begin{array}{l}\text { Level of evidence } \\
\text { 1a }\end{array}$ & (Albert US et al. 2008; NICE 2009b; NZGG 2009) \\
\hline $\begin{array}{l}\text { Grade of recom- } \\
\text { mendation } \\
\text { A }\end{array}$ & $\begin{array}{l}\text { b. Sonography should be used to especially to investigate } \\
\text { clinically non-palpable mammographic lesions with the } \\
\text { classifications BI-RADSO, III, IV and V. }\end{array}$ \\
\hline $\begin{array}{l}\text { Level of evidence } \\
\text { 2b }\end{array}$ & (NICE 2009b; Nothacker M et al. 2007) \\
\hline $\begin{array}{l}\text { Grade of recom- } \\
\text { mendation } \\
\text { A }\end{array}$ & $\begin{array}{l}\text { c. The aim of standardized breast sonography is the sys- } \\
\text { tematic and reproducible examination of both breasts } \\
\text { and the axilla. The findings must be documented in a re- } \\
\text { producible manner. }\end{array}$ \\
\hline $\begin{array}{l}\text { Level of evidence } \\
\mathbf{2 b}\end{array}$ & $\begin{array}{l}\text { (Albert US et al. 2008; Madjar H et al. 2006; Madjar H 2010; } \\
\text { NCCN 2011) }\end{array}$ \\
\hline & $\begin{array}{l}\text { d. Structural and process quality, as well as quality of out- } \\
\text { comes, should also be demonstrated as a prerequisite } \\
\text { for the use of breast sonography. }\end{array}$ \\
\hline GCP & (Albert US et al. 2008; Madjar H et al. 2006) \\
\hline
\end{tabular}

\begin{tabular}{ll}
$\begin{array}{l}\text { Stag-4 } \\
\begin{array}{l}\text { Grade of recom- } \\
\text { mendation }\end{array}\end{array}$ & $\begin{array}{l}\text { MRI with contrast medium } \\
\text { A } \begin{array}{l}\text { A contrast-enhanced MRI of the breasts should not be } \\
\text { routinely performed for pretherapeutic diagnosis. }\end{array}\end{array}$ \\
$\begin{array}{ll}\text { Level of evidence } \\
\text { 1a }\end{array}$ & $\begin{array}{l}\text { (Houssami N et al. 2008; NICE 2009b; NZGG 2009; Turnbull } \\
\text { Let al. 2010) }\end{array}$ \\
& $\begin{array}{l}\text { b. A CE-MRI should only be performed if an MRI-guided } \\
\text { intervention is a possible option. }\end{array}$ \\
\hline GCP &
\end{tabular}

\subsubsection{Diagnostic confirmation}

\begin{tabular}{|c|c|}
\hline Stag-5 & Imaging-guided minimally invasive biopsy \\
\hline $\begin{array}{l}\text { Grade of recom- } \\
\text { mendation } \\
\text { A }\end{array}$ & $\begin{array}{l}\text { a. The histological diagnostic investigation of unclear find- } \\
\text { ings should be carried out via core biopsy, vacuum-as- } \\
\text { sisted biopsy or excision biopsy. Core biopsy and vac- } \\
\text { uum-assisted biopsy can be performed mammographi- } \\
\text { cally and guided by ultrasound. Any interventions should } \\
\text { be performed taking current quality recommendations } \\
\text { into consideration. }\end{array}$ \\
\hline $\begin{array}{l}\text { Level of evidence } \\
\text { 3a }\end{array}$ & (Albert US et al. 2008; NICE 2009b) \\
\hline $\begin{array}{l}\text { Grade of recom- } \\
\text { mendation } \\
\text { A }\end{array}$ & $\begin{array}{l}\text { b. Fine-needle biopsy should not be employed as the stan- } \\
\text { dard method for diagnostic confirmation of solid breast } \\
\text { tumors. }\end{array}$ \\
\hline $\begin{array}{l}\text { Level of evidence } \\
\mathbf{2 b}\end{array}$ & (Albert US et al. 2008; NCCN 2011; NICE 2009b) \\
\hline $\begin{array}{l}\text { Grade of recom- } \\
\text { mendation } \\
\text { A }\end{array}$ & $\begin{array}{l}\text { c. In mammographic classification BI-RADS IV and V, in- } \\
\text { tervention-guided tissue biopsy for histopathological } \\
\text { confirmation of the diagnosis and for therapeutic plan- } \\
\text { ning should be performed using the imaging procedure } \\
\text { which best represents the findings and is the least inva- } \\
\text { sive. }\end{array}$ \\
\hline $\begin{array}{l}\text { Level of evidence } \\
\mathbf{3 a}\end{array}$ & (Albert US et al. 2008; NICE 2009b \\
\hline $\begin{array}{l}\text { Grade of recom- } \\
\text { mendation } \\
\text { A }\end{array}$ & $\begin{array}{l}\text { d. In the presence of microcalcifications without an ac- } \\
\text { companying focal lesion, stereotactically guided vac- } \\
\text { uum-assisted biopsy should preferably be performed. }\end{array}$ \\
\hline $\begin{array}{l}\text { Level of evidence } \\
\text { 2b }\end{array}$ & (Nothacker M et al. 2007) \\
\hline
\end{tabular}

\section{Stag-5 \\ Imaging-guided minimally invasive biopsy} (continuation)

e. Vacuum-assisted biopsy should also be used for MRIguided tissue sampling.

GCP

f. Following minimally invasive imaging-guided tissue sampling, the results should be verified by correlating the results of the imaging diagnostic studies with the histopathological findings.

GCP (Albert US et al. 2008; Del Turco MR et al. 2010)

g. If the histopathological examination reveals a benign lesion according to BI-RADS classification IV or V, a followup imaging study should be performed with the appropriate imaging method in 6-12 months' time. The quality requirements set down in the Stage 3 Guidelines for Early Breast Cancer Detection in Germany must be observed.

\section{GCP} (Albert US et al. 2008)

Grade of recom- h. When primary clinical and/or radiological findings sugmendation gest that axillary lymph nodes are involved, an imaging0 guided core biopsy can be performed as a minimally invasive procedure for cytohistological diagnostics to avoid superfluous axillary surgeries.

\section{Level of evidence (NICE 2009b)}

$3 a$

\section{Stag-6 Open excisional biopsy}

a. Primary, open diagnostic excision biopsy should only be performed in exceptional cases, as when an imagingguided intervention is not possible or too risky.

GCP (Albert US et al. 2008; Gruber R et al. 2008)

Grade of recom- b. In the case of non-palpable changes, it is always impormendation tant to perform preoperative marking. Adequate resecA tion via imaging methods must also be demonstrated. Level of evidence (Albert US et al. 2008)

3b

Grade of recom- c. During the preoperative wire marking of non-palpable mendation lesions, the wire should penetrate the focal lesion and A project beyond the lesion by less than $1 \mathrm{~cm}$. In cases where the wire does not penetrate the focal lesion, the distance between the wire and the margin of the lesion should be $\leq 1 \mathrm{~cm}$. In non-space-occupying processes, marking of the surgically relevant target volume may be useful.

Level of evidence (Albert US et al. 2008)

3b

d. The material collected during the operation should be clearly marked and sent to the pathologists without any incision of the tissue material obtained.

GCP (Albert US et al. 2008)

e. An intraoperative decision as to whether a lesion is benign or malignant on the basis of a frozen section should be made only in exceptional cases. Prerequisites for a frozen section of surgical specimens are:

- The lesion is palpable intraoperatively and in the specimen

- The lesion is sufficiently large (generally $>10 \mathrm{~mm}$ )

GCP

(Albert US et al. 2008)

\subsubsection{Staging}

\begin{tabular}{|c|c|}
\hline Stag-7 & Staging \\
\hline $\begin{array}{l}\text { Grade of recom- } \\
\text { mendation } \\
\text { A }\end{array}$ & $\begin{array}{l}\text { In patients with locally advanced carcinomas and in cases } \\
\text { where metastasis is suspected, the following individual } \\
\text { studies should be performed for staging prior to the insti- } \\
\text { tution of treatment: } \\
\text { - chest x-ray } \\
\text { - ultrasound examination of the liver } \\
\text { - bone scan }\end{array}$ \\
\hline $\begin{array}{l}\text { Level of evidence } \\
\mathbf{5}\end{array}$ & $\begin{array}{l}\text { (Alderson PO et al. 1983; Crump M et al. 1996; NICE 2009b; } \\
\text { NZGG 2009) }\end{array}$ \\
\hline
\end{tabular}




\subsection{Preinvasive neoplasms}

$\begin{array}{ll}\text { Preinv-1 } & \text { Therapeutic concept for preinvasive lesions } \\ & \text { Once a histological finding has been established from a } \\ \text { core/vacuum-assisted biopsy, the therapeutic strategy for } \\ \text { preinvasive neoplasms should be elaborated by an interdis- } \\ \text { ciplinary team consisting of a specialist in diagnostic radiol- } \\ \text { ogy, a surgeon and a pathologist. }\end{array}$

Preinv-2 Therapeutic concept for preinvasive lesions
An individualized treatment strategy should be elaborated
for and offered to every patient with ductal carcinoma in
situ (DCIS) without invasive portions. The patient must be
briefed on the arguments for and against the particular
therapies and combinations of these therapies, as well as on
the advantages with respect to the likelihood of local re-
currence and the absence of an effect on the probability of
survival.

\begin{tabular}{|c|c|}
\hline Preinv-3 & Operation \\
\hline $\begin{array}{l}\text { Grade of recom- } \\
\text { mendation } \\
\text { A }\end{array}$ & $\begin{array}{l}\text { a. The resection margin is an important prognostic factor } \\
\text { in DCIS. The tumor-free distance to the excision margin } \\
\text { should be at least } 2 \mathrm{~mm} \text { whenever postoperative radia- } \\
\text { tion therapy is planned. }\end{array}$ \\
\hline $\begin{array}{l}\text { Level of evidence } \\
\text { 2b }\end{array}$ & (Dunne C et al. 2009; NICE 2009; NZGG 2009) \\
\hline $\begin{array}{l}\text { Grade of recom- } \\
\text { mendation } \\
\text { A }\end{array}$ & $\begin{array}{l}\text { b. In DCIS, axillary dissection should not be performed. } \\
\text { A sentinel node biopsy should only be performed when a } \\
\text { secondary sentinel node biopsy is not possible for tech- } \\
\text { nical reasons. }\end{array}$ \\
\hline $\begin{array}{l}\text { Level of evidence } \\
\text { 1b }\end{array}$ & (Christiaens M et al. 2007; NZGG 2009) \\
\hline
\end{tabular}

\begin{tabular}{|c|c|}
\hline 4 & Radiotherapy \\
\hline $\begin{array}{l}\text { Grade of recom- } \\
\text { mendation } \\
\text { A }\end{array}$ & $\begin{array}{l}\text { a. Postoperative radiotherapy after breast-conserving sur- } \\
\text { gery for DCIS lowers the rate of invasive and non-invasive } \\
\text { local recurrences without any demonstrable effect on } \\
\text { overall survival. }\end{array}$ \\
\hline $\begin{array}{l}\text { Level of evidence } \\
\text { 1a }\end{array}$ & $\begin{array}{l}\text { (Bijker } \mathrm{N} \text { et al. 2006; Clarke M et al. 2005; Cochrane: Good- } \\
\text { win A et al. 2009; Cutuli B et al. 2002; Cuzick J et al. 2011; } \\
\text { EBCTCG: Correa C et al. 2010; Emdin SO et al. 2006; Holm- } \\
\text { berg L et al. 2008) }\end{array}$ \\
\hline $\begin{array}{l}\text { Grade of recom- } \\
\text { mendation } \\
\text { A }\end{array}$ & $\begin{array}{l}\text { b. The absolute risk reduction in the local recurrence rate } \\
\text { by radiotherapy after breast-conserving surgery for DCIS } \\
\text { depends on individual factors. }\end{array}$ \\
\hline $\begin{array}{l}\text { Level of evidence } \\
\mathbf{1 b}\end{array}$ & $\begin{array}{l}\text { (Baxter NN et al. 2005; Boyages J et al. 1999; Cochrane: } \\
\text { Goodwin A et al. 2009; Cuzick J et al. 2011; EBCTCG: Correa } \\
\text { C et al. 2010; Houghton J et al. 2003; Omlin A et al. 2006; } \\
\text { Shelley W et al. 2006; Smith BD et al. 2006) }\end{array}$ \\
\hline
\end{tabular}

$\begin{array}{ll}\text { Preinv-5 } & \text { Pharmacotherapy } \\ & \text { Tamoxifen can lower the risk for an ipsilateral and contra- } \\ \text { lateral recurrence of a DCIS. There is no effect on survival. } \\ \text { The decision for the adjuvant use of tamoxifen should be } \\ \text { made individually after weighing the benefits and side- } \\ \text { effects. }\end{array}$

\subsection{Surgical treatment of invasive carcinoma \\ 4.4.1 General recommendation}

Surg-1
$\begin{aligned} & \text { Tumor resection } \\ & \text { a. Tumor excision with a negative resection margin (R0 } \\ & \text { status) is the basis of therapy for all non-advanced breast } \\ & \text { carcinomas. }\end{aligned}$
$\begin{aligned} & \text { (Blichert-Toft M et al. 1998; Renton SC et al. 1996) } \\ & \text { b. The resection margin status has a prognostic effect in } \\ & \text { invasive breast carcinoma. There is a significant relation- } \\ & \text { ship between the resection margin status (positive vs. } \\ & \text { close vs. negative) and the local recurrence rate. }\end{aligned}$
$\begin{aligned} & \text { (Houssami N et al. 2010) } \\ & \text { 3a }\end{aligned}$

\section{Surg-2 Minimum safety distance}

Grade of recom- For this reason, the minimum safety distance in invasive mendation breast carcinoma between the tumor (invasive carcinoma A and associated DCIS) and the resection margin should be at least $1 \mathrm{~mm}$.

Level of evidence (Houssami N et al. 2010; NZGG 2009)

3a

\subsubsection{Breast-conserving treatment}

\begin{tabular}{|l|l|}
\hline Surg-3 & Breast-conserving treatment \\
& $\begin{array}{l}\text { a. The objective of surgical treatment is removal of the tu- } \\
\text { mor. Breast-conserving treatment (BCT) followed by ra- } \\
\text { diotherapy of the whole breast is equivalent in terms of } \\
\text { survival to modified radical mastectomy (MRM) alone. }\end{array}$ \\
\hline $\begin{array}{l}\text { Level of evidence } \\
\text { (EBCTCG 1995; Fisher B et al. 2001; Veronesi U et al. 2002; }\end{array}$ & $\begin{array}{l}\text { Wald NJ et al. 1995; Weaver DL et al. 2000) } \\
\text { b. For this reason, all patients should be briefed on the op- } \\
\text { tions of breast-conserving treatment (BCT) and modi- } \\
\text { fied radical mastectomy (MRM) with the possibility of } \\
\text { primary or secondary reconstruction. }\end{array}$ \\
\hline GCP & (NZGG 2009)
\end{tabular}

\subsubsection{Mastectomy}




\subsubsection{Plastic reconstructive procedures}

$\begin{array}{ll}\begin{array}{l}\text { Surg-5 } \\ \text { Grade of recom- }\end{array} & \begin{array}{l}\text { Breast reconstruction } \\ \text { mendation }\end{array} \\ \begin{array}{ll}\text { Avery patient due to undergo a mastectomy should be in- } \\ \text { formed about the possibility of immediate or later breast } \\ \text { reconstruction or of not having any reconstructive proce- } \\ \text { dure at all; contact with other patients or self-help groups } \\ \text { or organizations should also be offered. }\end{array} \\ \begin{array}{ll}\text { Level of evidence } \\ \text { (Lb }\end{array}\end{array}$

\subsubsection{Surgical treatment of the axilla}

\begin{tabular}{|c|c|}
\hline \multirow[t]{2}{*}{ Surg-6 } & Surgical treatment of the axilla \\
\hline & $\begin{array}{l}\text { a. Determination of the histological node status (pN sta- } \\
\text { tus) is part of the surgical treatment of invasive breast } \\
\text { cancer. This should be done by means of sentinel lymph } \\
\text { node biopsy (SLNB). }\end{array}$ \\
\hline \multirow[t]{2}{*}{ GCP } & $\begin{array}{l}\text { (Kuehn T et al. 2005; Lyman GH et al. 2005; NICE 2009; } \\
\text { NZGG 2009) }\end{array}$ \\
\hline & $\begin{array}{l}\text { b. SLNB is equivalent to axillary dissection in terms of local } \\
\text { control in SLN-negative patients. }\end{array}$ \\
\hline \multirow{2}{*}{$\begin{array}{l}\text { Level of evidence } \\
\mathbf{1 b}\end{array}$} & (Krag DN et al. 2010; NZGG 2009) \\
\hline & $\begin{array}{l}\text { c. Morbidity after SLNB is significantly reduced compared } \\
\text { with axillary dissection. }\end{array}$ \\
\hline \multirow[t]{2}{*}{$\begin{array}{l}\text { Level of evidence } \\
\text { 1a }\end{array}$} & $\begin{array}{l}\text { (Fleissig A et al. 2006; Mansel RE et al. 2006; NICE 2009; } \\
\text { Veronesi U et al. 2003) }\end{array}$ \\
\hline & $\begin{array}{l}\text { d. Axillary dissection must be performed in patients in } \\
\text { whom no SLN is detected. }\end{array}$ \\
\hline \multicolumn{2}{|l|}{ GCP } \\
\hline $\begin{array}{l}\text { Grade of recom- } \\
\text { mendation } \\
\text { A }\end{array}$ & $\begin{array}{l}\text { e. In patients who exhibit a positive SLN (macrometasta- } \\
\text { sis), axillary dissection with removal of at least } 10 \text { lymph } \\
\text { nodes from levels I and II is indicated. }\end{array}$ \\
\hline \multirow{2}{*}{$\begin{array}{l}\text { Level of evidence } \\
\mathbf{1 b}\end{array}$} & (NZGG 2009) \\
\hline & $\begin{array}{l}\text { f. For patients with pT1-pT2/cN0 tumors undergoing } \\
\text { breast-conserving surgery followed by tangential field } \\
\text { irradiation and who exhibit one or two positive sentinel } \\
\text { lymph nodes, there is the option of refraining from axil- } \\
\text { lary dissection. }\end{array}$ \\
\hline \multirow[t]{3}{*}{ GCP } & (Giuliano AE et al. 2010) \\
\hline & $\begin{array}{l}\text { g. This procedure requires extensive preliminary informa- } \\
\text { tion and briefing of the patient. }\end{array}$ \\
\hline & $\begin{array}{l}\text { The process and outcome quality must be evaluated pro- } \\
\text { spectively in conjunction with quality assuring measures. }\end{array}$ \\
\hline \multicolumn{2}{|l|}{ GCP } \\
\hline & $\begin{array}{l}\text { h. Axillary dissection is not necessary if only micrometasta- } \\
\text { ses are present. }\end{array}$ \\
\hline & \\
\hline
\end{tabular}

\section{Surg-7 Removal of sentinel lymph nodes}

If the sentinel lymph node is removed, the quality criteria of the medical associations must be met.

GCP (Kuehn T et al. 2005; Lyman GH et al. 2005; NICE 2009)

\subsection{Pathomorphological examination \\ 4.5.1 Preliminary remarks} (no statements)

\subsubsection{General principles}

\section{Patho-1 General principles for surgical material}

The surgical material should be identified with unambiguous topographical markings and sent to the pathologist without the prior removal of any tissue by the clinician or surgeon (or others).

GCP (Amendoeira I 2006b; NCCN 2011)

$\begin{array}{ll}\text { Patho-2 } & \begin{array}{l}\text { Histological classification of invasive carcinomas } \\ \text { All invasive carcinomas must be classified histologically } \\ \text { (according to WHO 2003). }\end{array} \\ \text { GCP } & \begin{array}{l}\text { (Amendoeira I 2006b; NCCN 2011; NHMRC2001; The As- } \\ \text { sociation of Breast Surgery at BASO RCOSoE 2005; WHO } \\ \text { 2003) }\end{array}\end{array}$

Patho-3 Grading of invasive carcinomas

All invasive carcinomas are to be graded according to the WHO system (Elston and Ellis modification of the Bloom and Richardson grading (Elston CW et al. 1991)).

GCP

\begin{tabular}{|c|c|}
\hline Patho-4 & $\begin{array}{l}\text { Hormone receptor (ER/PgR) and HER2 status of inva- } \\
\text { sive carcinomas }\end{array}$ \\
\hline $\begin{array}{l}\text { Grade of recom- } \\
\text { mendation } \\
\text { A }\end{array}$ & $\begin{array}{l}\text { a. In patients with invasive breast carcinoma, the primary } \\
\text { diagnostic procedures should include determination of } \\
\text { the estrogen and progesterone receptor status and of } \\
\text { the HER2 status, preferably directly on the core biopsy. }\end{array}$ \\
\hline \multirow[t]{2}{*}{$\begin{array}{l}\text { Level of evidence } \\
2 \mathbf{a}\end{array}$} & $\begin{array}{l}\text { (Hammond ME et al. 2010; ICSI 2005; NCCN 2011; } \\
\text { NHMRC2001; NICE 2009; NZGG 2009; Wolff AC et al. } \\
\text { 2007a) }\end{array}$ \\
\hline & $\begin{array}{l}\text { b. The estrogen and progesterone receptor status should } \\
\text { be determined by immunohistochemistry assay. The } \\
\text { percentages of positive tumor cell nuclei and the mean } \\
\text { color intensity should be stated for each receptor type. } \\
\text { In addition, scores can be calculated, in which case the } \\
\text { procedure used should be specified (Allred (Quick) } \\
\text { Score, Immunoreactive Score of Remmele and Stegner). } \\
\text { At least } 1 \% \text { positive tumor cell nuclei are required for } \\
\text { classification as ER- or PgR-positive. }\end{array}$ \\
\hline GCP & $\begin{array}{l}\text { (Hammond ME et al. 2010; NCCN 2011; NICE 2009; } \\
\text { NZGG } 2009\end{array}$ \\
\hline $\begin{array}{l}\text { Grade of recom- } \\
\text { mendation } \\
\text { A }\end{array}$ & $\begin{array}{l}\text { C. HER2 positivity as a precondition for trastuzumab ther- } \\
\text { apy is defined as protein overexpression with a score of } 3 \\
+ \text { demonstrated by immunohistochemistry assay, or } \\
\text { gene amplification demonstrated preferably by fluores- } \\
\text { cence in situ hybridization (FISH) or chromogenic in situ } \\
\text { hybridization (CISH). }\end{array}$ \\
\hline \multirow[t]{2}{*}{$\begin{array}{l}\text { Level of evidence } \\
\mathbf{1 b}\end{array}$} & $\begin{array}{l}\text { (Carlson RW et al. 2006; Crump M 2005; NCCN 2011; } \\
\text { NCRI 2005; Nothacker M et al. 2007; Wolff AC et al. 2007a) }\end{array}$ \\
\hline & $\begin{array}{l}\text { d. It must be ensured that the detection method used to } \\
\text { determine the hormone receptor and HER2 status is re- } \\
\text { liable. This involves internal test validation, the use of } \\
\text { standardized protocols and internal controls, and regular } \\
\text { successful participation in external quality assurance } \\
\text { measures. }\end{array}$ \\
\hline GCP & $\begin{array}{l}\text { (Carlson RW et al. 2006; Hammond ME et al. 2010; NCCN } \\
\text { 2011; NICE 2009; NZGG 2009; Wolff AC et al. 2007a) }\end{array}$ \\
\hline
\end{tabular}




\section{Patho-5.1 Prognosis and prediction}

The tumor characteristics and the patient's situation must be documented in order to be able to assess the course of the disease (prognosis) and the expected effect of systemic therapies (prediction).

The following should be documented as prognostic factors:

Grade of recom- a. pTNM status (tumor size, axillary lymph node involve-

mendation ment, distant metastasis)

A

Level of evidence (Bundred NJ 2001; Carter CL et al. 1989; NCCN 2011; NZGG 1a

\section{Grade of recom-}

mendation

A

Level of evidence (Bundred NJ 2001; Kurtz JM et al. 1989; NCCN 2011;

1b NICE 2009; NZGG 2009; Park CC et al. 2000)

Grade of recom- c. histological type

mendation

A

Level of evidence （Fisher ER et al. 1990; NCCN 2011; NZGG 2009)

$2 b$

Grade of recom- d. tumor grade

mendation

A

Level of evidence （Elston CW et al. 1991; NCCN 2011; NZGG 2009)

$2 a$

\begin{tabular}{|c|c|}
\hline $\begin{array}{l}\text { Level of evidence } \\
\mathbf{2 b}\end{array}$ & $\begin{array}{l}\text { (Colleoni M et al. 2007; Gasparini G et al. 1994; Kato T et al. } \\
\text { 2003; NCCN 2011; NZGG 2009) }\end{array}$ \\
\hline & f. $A$ \\
\hline
\end{tabular}

\section{GCP}

Grade of recom- g. In the case of node-negative breast cancers, the determendation mination of tumor concentrations of UPA and PAI- 1 by $0 \quad$ ELISA can provide additional prognostic information.

Level of evidence (Harbeck N et al. 2009; Harris L et al. 2007; Janicke F et al. $1 \mathrm{a}$ 2001; Look MP et al. 2002)

The following predictive factors for adjuvant therapy should be documented:

Grade of recom- h. Estrogen/progesterone receptor status for hormone mendation therapy

A

Level of evidence (Bundred NJ 2001; EBCTCG 1992; EBCTCG 1998; NCCN

1a 2011; Osborne CK 1998)

Grade of recom- i. HER2/neu status for targeted anti-HER2 treatment mendation

A

Level of evidence (NCCN 2011; NICE 2009; Nothacker M et al. 2007; NZGG

1b 2009)

Grade of recom- j. Menopausal status for use of antiestrogen therapy.

mendation

A

Level of evidence $\quad$ (EBCTCG 2000; NCCN 2011)

1c

k. The prognostic and predictive value of the proliferation marker Ki-67 is not sufficiently documented. Outside of studies, therefore, it cannot be used clinically for subtyping ER-positive breast cancers (e.g. Ki-67 < 14\%: luminal A; Ki-67 $\geq 14 \%$ : luminal B) as a basis for deciding on the use of systemic treatment.

GCP (de Azambuja E et al. 2007; Dowsett M et al. 2011; StuartHarris R et al. 2008; Yerushalmi R et al. 2010)

I. The use of gene expression analyses - PCR-based or by microarray - for evaluation of the prognosis or response to treatment (prediction) is not sufficiently validated for routine use and can therefore not be recommended.

S et al. 2004; Paik S et al. 2006)

\begin{tabular}{ll} 
Patho-5.2 & Predictive factors in connection with neoadjuvant \\
& systemic treatment \\
Grade of recom- & Predictive factors that should be taken into account before \\
mendation & administering neoadjuvant systemic treatment because \\
A & they hold significant predictive value for the occurrence of a \\
& pathological complete remission (PCR)§: \\
& - Age \\
& D cT \\
& - cN \\
& D histological type \\
& D histological grading \\
& - ER and PgR status \\
& - HER2 status \\
& (von Minckwitz G et al. 2011) \\
\hline Level of evidence &
\end{tabular}

Patho-6 Frozen section examination
An intraoperative decision as to whether a lesion is benign
or malignant on the basis of a frozen section should be
made only in exceptional cases.
Prerequisites for a frozen section of surgical specimens are:
- The lesion is palpable intraoperatively and in the speci-
men
(Amendoeira I 2006b; NHMRC2001; NZGG 2009; O'Hig-
GCP
gins N et al. 1998)

\subsubsection{Percutaneous biopsies used in connection with interventional diagnostic procedures (no statements)}

\subsubsection{Excisional biopsies}

(no statements)

\subsubsection{Mastectomy specimens (no statements)}

\subsubsection{Lymph nodes}

$\begin{array}{ll}\text { Patho-7 } & \text { Lymph node status } \\ \text { The lymph node status is determined on the basis of histo- } \\ \text { logical examination of all the lymph nodes removed. } \\ \text { Documentation of the following is mandatory: number of } \\ \text { lymph nodes removed and involved, capsule penetration, } \\ \text { PN category (according to TNM classification, 76th Edition, } \\ \text { UICC20 022010). } \\ \text { (ICSI 2005; NHMRC2001; NZGG 2009; The Association of } \\ \text { Breast Surgery at BASO RCOSoE 2005; UICC2010) }\end{array}$


4.6 Adjuvant radiotherapy of breast cancer

4.6.1 Radiotherapy after breast-conserving surgical treatment

\begin{tabular}{|c|c|}
\hline RT-1 & $\begin{array}{l}\text { Radiotherapy after breast-conserving surgical treat- } \\
\text { ment (general) }\end{array}$ \\
\hline $\begin{array}{l}\text { Grade of recom- } \\
\text { mendation } \\
\text { A }\end{array}$ & $\begin{array}{l}\text { In patients with invasive carcinoma, irradiation of the af- } \\
\text { fected breast is indicated after breast-conserving surgery. }\end{array}$ \\
\hline $\begin{array}{l}\text { Level of evidence } \\
\text { 1a }\end{array}$ & $\begin{array}{l}\text { (Clarke M et al. 2005; EBCTCG 2011: Darby S et al. 2011; } \\
\text { EBMG 2006; Harnett A et al. 2009; NZGG 2009; Peto R } \\
\text { 2006) }\end{array}$ \\
\hline
\end{tabular}

\section{RT-2}

Administration of radiotherapy after breast-conserving therapy (BCT)

Grade of recommendation

A

Level of evidence

1a

Grade of recom-

mendation

A

Level of evidence

1a

Grade of recommendation

B

Level of evidence
$\mathbf{1 a}$
Grade of recom-
mendation

mendation

A

a. The target volume of percutaneous adjuvant radiotherapy should encompass the entire residual breast and the adjoining chest wall.

(EBCTCG 2011: Darby S et al. 2011; EBMG 2006; NCCN 2007; NHMRC2001; NICE 2009; NZGG 2009; SIGN 2005)

b. The dose should be approx. $50 \mathrm{~Gy}$ in conventional fractionation (5 × 1.8-2.0 Gy/week).

(Clarke M et al. 2005; EBCTCG 2011: Darby S et al. 2011; EBMG 2006; NCCN 2011; NHMRC2001; Peto R 2006; SIGN 2005)

c. In older patients without locoregional lymph node involvement and with tumors $<5 \mathrm{~cm}$ who do not require chemotherapy, hypofractionated regimens can also be used as an alternative to conventionally fractionated radiotherapy for percutaneous homogeneous irradiation of the breast (e.g., $5 \times 2.666$ Gy per week up to $40 \mathrm{~Gy}$ ).

(Goldhirsch A et al. 2011; Harnett A 2010; NCCN 2011; NICE 2009; Smith BD et al. 2011a; Whelan T] et al. 2010)

$\mathrm{d}$. The application of a local booster dose (boost irradiation) to the tumor bed reduces the rate of local recurrence in the breast without conferring an advantage in terms of survival.

Boost irradiation is generally indicated. The recommended boost dose is (10-)16 Gy in conventional fractionation (5 × 1.8-2.0 Gy/week).

Level of evidence (Antonini N et al. 2007; Bartelink H et al. 2007; Jones HA et 1a al. 2009; Livi L et al. 2009; Poortmans P 2007; Poortmans PM et al. 2008; Poortmans PM et al. 2009; Romestaing P et al. 1997; Romestaing P et al. 2009; Sautter-Bihl ML et al. 2007; SIGN 2005)

Grade of recom- e. In postmenopausal patients with a very low risk of local mendation

C recurrence (in particular, age $>60$ years, small tumors and favorable prognostic factors), the absolute advantage conferred by boost irradiation is small. In this subgroup, the administration of boost irradiation may be omitted if necessary.

Level of evidence (EBCTCG 2011: Darby S et al. 2011; NZGG 2009)

\subsubsection{Radiotherapy of the chest wall after mastectomy}

RT-4

Level of evidence

Level of evidence

1 a
Radiotherapy of the chest wall after mastectomy

a. Postoperative radiotherapy of the chest wall after mastectomy reduces the risk of locoregional recurrence.

(Clarke M et al. 2005; EBMG 2006; NCCN 2011; NHMRC2001; NICE 2009; NZGG 2009; Peto R 2006; Shafiq J et al. 2007; SIGN 2005; Whelan T et al. 2007)

b. In patients with a high risk of a local recurrence, overall survival is also improved. (Clarke M et al. 2005; Darby S et al. 2009; Fernando SA et al. 2007; Gebski V et al. 2006; Harris EE 2008; Jagsi R et al. 2009; Kyndi M et al. 2008b; Kyndi M et al. 2008a; NCCN 2011; NICE 2009; Nielsen HM et al. 2006a; Nielsen HM et al. 2006b; NZGG 2009; Overgaard M et al. 2007; Peto R 2006; Poortmans P 2007; Rowell NP 2009; Rowell NP 2010; Voordeckers M et al. 2009; Whelan T et al. 2007)

c. Postoperative radiotherapy of the chest wall after mastectomy is therefore indicated in the following situations:

Grade of recom- $\quad$ T3/T4

mendation

A

Level of evidence $\quad$ (NCCN 2011; NICE 2009; NZGG 2009)

1 a

Grade of recom- $\quad$ pT3 pN0 R0 only in the presence of other risk factors mendation (lymphatic vessel invasion, G3 grade, close resection B Level of evidence (Floyd SR et al. 2009; Kunkler I 2010; McCammon R et al. 2b 2008; Rowell NP 2009; Russell NS et al. 2009)

Grade of recom- $\quad$ R1-/R2 resection and no possibility of a complete remendation

A

Level of evidence $\quad$ (NCCN 2011; NICE 2009; NZGG 2009)

1 a

Grade of recom- $\quad \mathrm{pN}+(>3$ lymph nodes)

mendation

A

Level of evidence $\quad$ (NCCN 2011; NICE 2009; NZGG 2009)

$1 \mathrm{a}$

Grade of recom- d. After primary (neoadjuvant) systemic therapy, the indimendation

A cation for radiotherapy should be based on the pretherapeutic $\mathrm{T}$ and $\mathrm{N}$ category, regardless of the degree of response to the primary systemic therapy.

Level of evidence (Buchholz TA et al. 2002; Buchholz TA et al. 2008; Buchholz

$2 a$
TA 2009; Garg AK et al. 2007; Goldhirsch A et al. 2009; Huang EH et al. 2006; Kaufmann M et al. 2003; Kaufmann M et al. 2010; NCCN 2007; NCCN 2011)

\subsubsection{Partial breast irradiation}

RT-3 Radiotherapy confined to parts of the breast (partial breast irradiation, $\mathrm{PBI}$ ) as the sole form of irradiation, including intraoperative radiotherapy (IORT) alone Partial breast irradiation as the sole form of intraoperative or postoperative radiation treatment is not standard therapy

Level of evidence (NCCN 2006; NCCN 2007) 


\subsubsection{Radiotherapy of the regional lymphatic drainage system}

\begin{tabular}{|c|c|}
\hline RT-5 & $\begin{array}{l}\text { Radiotherapy of the regional lymphatic drainage } \\
\text { system }\end{array}$ \\
\hline $\begin{array}{l}\text { Grade of recom- } \\
\text { mendation } \\
\text { A }\end{array}$ & $\begin{array}{l}\text { a. In a pN0 situation, the regional lymphatic drainage areas } \\
\text { should not undergo adjuvant irradiation. }\end{array}$ \\
\hline \multirow[t]{2}{*}{$\begin{array}{l}\text { Level of evidence } \\
\mathbf{3 b}\end{array}$} & (NCCN 2011; NICE 2009) \\
\hline & $\begin{array}{l}\text { b. Radiotherapy of the axilla is recommended only in the } \\
\text { following situations: }\end{array}$ \\
\hline $\begin{array}{l}\text { Grade of recom- } \\
\text { mendation } \\
\text { A }\end{array}$ & - residual tumor in the axilla \\
\hline $\begin{array}{l}\text { Level of evidence } \\
\mathbf{2 b}\end{array}$ & $\begin{array}{l}\text { (NCCN 2011; NICE 2009; NZGG 2009; SIGN 2005; Truong } \\
\text { PT et al. 2004; Truong PT et al. 2005b) }\end{array}$ \\
\hline $\begin{array}{l}\text { Grade of recom- } \\
\text { mendation } \\
\text { A }\end{array}$ & $\begin{array}{l}\text { unequivocal clinical involvement and in the absence of } \\
\text { axillary dissection. }\end{array}$ \\
\hline $\begin{array}{l}\text { Level of evidence } \\
\mathbf{3 b}\end{array}$ & (NCCN 2011; NICE 2009; NZGG 2009) \\
\hline $\begin{array}{l}\text { Grade of recom- } \\
\text { mendation } \\
\text { A }\end{array}$ & $\begin{array}{l}\text { c. The benefit of radiotherapy of the regional lymphatic } \\
\text { drainage channels following detection of isolated tumor } \\
\text { cells or micrometastases in regional lymph nodes } \\
\text { (pNmic) is not substantiated and therefore it should not } \\
\text { be performed. }\end{array}$ \\
\hline $\begin{array}{l}\text { Level of evidence } \\
\mathbf{3 b}\end{array}$ & $\begin{array}{l}\text { (de Boer M et al. 2009; de Boer M et al. 2010; Lupe K et al. } \\
\text { 2011; Tjan-Heijnen VC et al. 2009; Truong PT et al. 2008) } \\
\text { d. Radiotherapy of the internal mammary lymph node } \\
\text { drainage region should not be performed. }\end{array}$ \\
\hline GCP & $\begin{array}{l}\text { (NICE 2009; NZCG 2009) } \\
\text { e. Radiotherapy of the supraclavicular and infraclavicular } \\
\text { lymphatic drainage channels is recommended in the } \\
\text { following situations: }\end{array}$ \\
\hline $\begin{array}{l}\text { Grade of recom- } \\
\text { mendation } \\
\text { B }\end{array}$ & - patients with $>3$ positive axillary lymph nodes ( $>$ pN2a) \\
\hline $\begin{array}{l}\text { Level of evidence } \\
\mathbf{1 b}\end{array}$ & (NICE 2009; NZGG 2 \\
\hline $\begin{array}{l}\text { Grade of recom- } \\
\text { mendation } \\
\text { B }\end{array}$ & - level III axillary involvement \\
\hline $\begin{array}{l}\text { Level of evidence } \\
\mathbf{3 b}\end{array}$ & (NZGG 2009; SIGN 2005) \\
\hline $\begin{array}{l}\text { Grade of recom- } \\
\text { mendation } \\
\text { B }\end{array}$ & $\begin{array}{l}\text { where irradiation of the axilla is indicated (residual tumor } \\
\text { in the axilla) }\end{array}$ \\
\hline $\begin{array}{l}\text { Level of evidence } \\
\mathbf{3 b}\end{array}$ & (NZGG 2009; SIGN 2005) \\
\hline & $\begin{array}{l}\text { f. The indication for radiotherapy of the regional lymph } \\
\text { drainage channels following primary systemic therapy } \\
\text { should be dependent on the pretherapeutic baseline sit- } \\
\text { uation and independent of the response of the tumor } \\
\text { manifestations to systemic therapy. }\end{array}$ \\
\hline $\begin{array}{l}\text { Level of evidence } \\
\mathbf{3 b}\end{array}$ & $\begin{array}{l}\text { (Buchholz TA et al. 2002; Garg AK et al. 2007; Huang EH et } \\
\text { al. 2006; Kaufmann M et al. 2010; McGuire SE et al. 2007; } \\
\text { NCCN 2011) }\end{array}$ \\
\hline & $\begin{array}{l}\text { g. } \\
\text { Where irradiation of lymphatic drainage areas is indicated, } \\
\text { radiotherapy is administered with approx. } 50 \text { Gy in conven- } \\
\text { tional fractionation }(5 \times 1.8-2.0 \text { Gy/week). For irradiation } \\
\text { of the supraclavicular lymphatic drainage region, a single } \\
\text { dose of } 1.8 \text { Gy should be preferred. }\end{array}$ \\
\hline
\end{tabular}

\subsubsection{Radiotherapy of advanced or inoperable tumors}

\begin{tabular}{ll} 
RT-6 & $\begin{array}{l}\text { Radiotherapy for locally very advanced tumors and } \\
\text { primary inoperability }\end{array}$ \\
$\begin{array}{ll}\text { Grade of recom- } \\
\text { mendation }\end{array}$ & $\begin{array}{l}\text { a. Primary systemic therapy followed by surgery and post- } \\
\text { operative radiotherapy is recommended for patients } \\
\text { with primarily inoperable or inflammatory carcinomas. }\end{array}$ \\
\hline A & $\begin{array}{l}\text { (Kaufmann M et al. 2003; Kaufmann M et al. 2010; NCCN } \\
\text { Level of evidence }\end{array}$ \\
\hline 1b & $\begin{array}{l}\text { 2011; NICE 2009 } \\
\text { b. If systemic therapy fails to achieve operability, radio- } \\
\text { therapy - possibly in combination with simultaneous } \\
\text { systemic therapy - is indicated. }\end{array}$ \\
& $\begin{array}{l}\text { (Kaufmann M et al. 2003; Kaufmann M et al. 2010; NCCN } \\
\text { GCP }\end{array}$ \\
& 2007; NCCN 2011; Shenkier T et al. 2004; Truong PT et al.
\end{tabular}

4.6.6 Sequencing of chemotherapy, antibody therapy, systemic endocrine therapy and hormonal therapy

\begin{tabular}{|c|c|}
\hline RT-7 & Sequencing of chemotherapy and radiotherapy \\
\hline $\begin{array}{l}\text { Grade of recom- } \\
\text { mendation } \\
\text { B }\end{array}$ & $\begin{array}{l}\text { The superiority of a particular chronological sequence of } \\
\text { chemotherapy and radiotherapy has not been sufficiently } \\
\text { established. As a basic rule, the postoperative sequence } \\
\text { depends on the type of recurrence most likely to occur, } \\
\text { especially since the optimal time is not sufficiently sub- } \\
\text { stantiated. }\end{array}$ \\
\hline $\begin{array}{l}\text { Level of evidence } \\
\text { 1a }\end{array}$ & $\begin{array}{l}\text { (Cochrane: Hickey BE et al. 2006; Kaufmann M et al. 2010; } \\
\text { NCCN 2011; NICE 2009; Poortmans P 2007; Recht A 2003; } \\
\text { Recht A 2010; Rouesse J et al. 2006; Tsoutsou PG et al. } \\
\text { 2010) }\end{array}$ \\
\hline
\end{tabular}

RT-8 Sequencing of antibody therapy and radiotherapy The concurrent administration of trastuzumab and radiotherapy can be justified as long as no irradiation of the internal mammary lymph nodes is planned.

GCP (Azria D et al. 2010b; Balduzzi A et al. 2010; Belkacemi Y et al. 2008; Chargari C et al. 2011a; Chargari C et al. 2011b; Halyard MY et al. 2009; Kirova YM et al. 2009; Romond EH et al. 2005; Shaffer R et al. 2009)

RT-9 Sequencing systemic endocrine therapy and radio-
therapy Endocrine treatment modalities can be performed concurrently or sequentially with radiotherapy.

Level of evidence (Ahn PH et al. 2005; Harris EE et al. 2005; Hoeller U et al. $1 a$ 2007; Pierce LJ et al. 2005; Whelan T et al. 2005) 


\subsection{Systemic adjuvant therapy (endocrine therapy,} chemotherapy and antibody therapy)

\begin{tabular}{|c|c|}
\hline Adj-1 & $\begin{array}{l}\text { Diagnostic procedures before the start of chemo- } \\
\text { therapy }\end{array}$ \\
\hline & $\begin{array}{l}\text { A sentinel node biopsy should be performed before the be- } \\
\text { ginning of neoadjuvant chemotherapy in patients with cNO; } \\
\text { in those with cN1, the diagnosis can also be made by core } \\
\text { biopsy or fine-needle biopsy. }\end{array}$ \\
\hline \multicolumn{2}{|l|}{ GCP } \\
\hline Adj-2 & Pharmacotherapy of the primary disease \\
\hline $\begin{array}{l}\text { Grade of recom- } \\
\text { mendation } \\
\text { A }\end{array}$ & $\begin{array}{l}\text { Pharmacotherapy of the primary disease is undertaken be- } \\
\text { fore or after surgery in the form of chemotherapy, endo- } \\
\text { crine therapy, anti-HER } 2 \text { antibody therapy or a combination } \\
\text { or sequence of these different forms. }\end{array}$ \\
\hline $\begin{array}{l}\text { Level of evidence } \\
\text { 1a }\end{array}$ & (EBCTCG 2005; NCCN 2006) \\
\hline
\end{tabular}

\subsubsection{Endocrine therapy}

$\begin{array}{ll}\begin{array}{l}\text { Adj-6 } \\ \begin{array}{l}\text { Grade of recom- } \\ \text { mendation }\end{array}\end{array} & \begin{array}{l}\text { Indications for endocrine therapy } \\ \text { and/or progesterone receptor-positive tumors. }\end{array} \\ \begin{array}{ll}\text { A } \\ \text { Level of evidence }\end{array} & \begin{array}{l}\text { (EBCTCG 1998; EBCTCG: Davies C et al. 2011; Fisher B et al. } \\ \text { 1a }\end{array} \\ \begin{array}{l}\text { Grade of recom- } \\ \text { mendation }\end{array} & \begin{array}{l}\text { b. This should not be initiated until after chemotherapy has } \\ \text { been completed. }\end{array} \\ \text { A } & \begin{array}{l}\text { (EBCTCG 1998; EBCTCG: Davies C et al. 2011; Fisher B et al. } \\ \text { Level of evidence } \\ \text { 1a }\end{array}\end{array}$

$\begin{array}{ll}\begin{array}{l}\text { Adj-7 } \\ \text { Grade of recom- }\end{array} & \begin{array}{l}\text { Therapy in premenopausal patients } \\ \text { In premenopausal patients, tamoxifen is the endocrine } \\ \text { mendation }\end{array} \\ \begin{array}{ll}\text { A } & \begin{array}{l}\text { therapy of choice. Antihormonal therapy with tamoxifen } \\ \text { until recurrence. }\end{array} \\ \begin{array}{l}\text { Level of evidence } \\ \text { 1a }\end{array} & \text { (EBCTCG 1998; EBCTCG: Davies C et al. 2011) }\end{array}\end{array}$

\begin{tabular}{|c|c|}
\hline \multirow[t]{2}{*}{ Adj-3 } & Recurrence rate and mortality \\
\hline & $\begin{array}{l}\text { The recurrence rate and mortality can be reduced by sys- } \\
\text { temic therapy. This applies to polychemotherapy, in partic- } \\
\text { ular the administration of anthracyclines and taxanes, } \\
\text { pharmacological suppression of ovarian function, tamoxi- } \\
\text { fen, aromatase inhibitors and trastuzumab. The extent of } \\
\text { this effect in absolute terms depends on the disease risk. }\end{array}$ \\
\hline Level of evidence & (Cochrane: Ferguson T et al. 2007; EBCTCG 1998; EBCTCG \\
\hline $1 \mathrm{a}$ & 2005; EBCTCG 2011; NIH 2001) \\
\hline
\end{tabular}

\begin{tabular}{l} 
Adj-4 Supportive therapy \\
Optimal supportive therapy (e.g., stimulation of granulo- \\
poiesis, anti-emetic medication, provision of wigs, etc.) is \\
an integral part of all systemic therapies. All patients should \\
be briefed on possible side effects and late sequelae and \\
offered prophylactic measures. \\
\hline GCP
\end{tabular}

$\begin{aligned} & \text { Adj-5 } \\ & \begin{array}{l}\text { Grade of recom- } \\ \text { mendation }\end{array}\end{aligned}$
$\begin{aligned} & \text { Older* patients should receive similar systemic adjuvant } \\ & \text { B }\end{aligned}$
$\begin{aligned} & \text { therapy to that given to younger patients. Changes in organ } \\ & \text { when establishing the indication for and implementing ad- } \\ & \text { juvant treatment measures. }\end{aligned}$
$\begin{aligned} & \text { Level of evidence } \\ & \text { 1a }\end{aligned}$

* "Older" patients are deemed to be all patients $>65$ years. The deciding factors in the choice of adjuvant therapy are organ function and comorbidities.

\begin{tabular}{ll} 
Adj-8 & Therapy in postmenopausal patients \\
& $\begin{array}{l}\text { a. In women who are definitely postmenopausal, third- } \\
\text { generation aromatase inhibitors are superior to tamoxi- } \\
\end{array}$ \\
& fen in terms of disease-free survival. \\
\hline $\begin{array}{l}\text { Level of evidence } \\
\text { 1b }\end{array}$ & Burstein HJ et al. 2010; NZGG 2009) \\
& b. The following endocrine treatment regimens can be \\
& used: \\
& tamoxifen for 5 years \\
& aromatase inhibitors for 5 years \\
& tamoxifen for $2-3$ years followed by aromatase inhib- \\
& itors, up to a total treatment duration of 5 years \\
& aromatase inhibitors for $2-3$ years followed by tamoxi- \\
& fen, up to a total treatment duration of 5 years \\
& tamoxifen for 5 years followed by aromatase inhibitors \\
& for 5 years
\end{tabular}

\subsubsection{Chemotherapy}

\begin{tabular}{|c|c|}
\hline Adj-9 & Adjuvant chemotherapy in receptor-negative tumors \\
\hline $\begin{array}{l}\text { Grade of recom- } \\
\text { mendation } \\
\text { A }\end{array}$ & $\begin{array}{l}\text { a. All patients with receptor-negative tumors ( } \mathrm{pNO} \text { and } \mathrm{pN} \\
+ \text { ) should receive adjuvant chemotherapy. }\end{array}$ \\
\hline $\begin{array}{l}\text { Level of evidence } \\
\text { 1a }\end{array}$ & (EBCTCG 2011; NICE 2009; NZGG 2009) \\
\hline $\begin{array}{l}\text { Grade of recom- } \\
\text { mendation } \\
\text { A }\end{array}$ & $\begin{array}{l}\text { b. Chemotherapy should be administered at the recom- } \\
\text { mended dosages. }\end{array}$ \\
\hline $\begin{array}{l}\text { Level of evidence } \\
\text { 1a }\end{array}$ & $\begin{array}{l}\text { (Budman DR et al. 1998; EBCTCG 2011; Fisher B et al. 1997; } \\
\text { French Adjuvant Study Group 2001; Fumoleau Pet al. 2003) } \\
\text { c. Underdosing or a reduction in the number of cycles is li- } \\
\text { able to cause a loss of effectiveness. }\end{array}$ \\
\hline $\begin{array}{l}\text { Level of evidence } \\
\text { 1a }\end{array}$ & $\begin{array}{l}\text { (Bonadonna G et al. 1995; Budman DR et al. 1998; Cady B } \\
\text { et al. 1993; Fisher B et al. 1990; French Adjuvant Study } \\
\text { Group 2001) }\end{array}$ \\
\hline
\end{tabular}




\begin{tabular}{ll}
$\begin{array}{ll}\text { Adj-10 } \\
\text { Grade of recom- } \\
\text { mendation }\end{array}$ & $\begin{array}{l}\text { Administration of cytostatics } \\
\text { Cytotoxic agents should be administered concurrently or } \\
\text { sequentially. } \\
\text { A }\end{array}$ \\
\hline $\begin{array}{l}\text { Leve-dense treatments should be used in patients with an } \\
\text { increased risk of recurrence. }\end{array}$ \\
\hline 1b & $\begin{array}{l}\text { (Bonadonna G et al. 1995; Citron ML et al. 2003; Eiermann } \\
\text { W et al. 2011; Francis P et al. 2008; Moebus V et al. 2010; } \\
\text { NIH 2001) }\end{array}$ \\
\hline
\end{tabular}

\begin{tabular}{|c|c|}
\hline Adj-11 & Indications for adjuvant chemotherapy \\
\hline $\begin{array}{l}\text { Grade of recom- } \\
\text { mendation } \\
\text { B }\end{array}$ & $\begin{array}{l}\text { An indication for adjuvant chemotherapy should be estab- } \\
\text { lished in the case of: } \\
\text { - HER2-positive tumors } \\
\text { - Tumors that are not sensitive to endocrine therapy } \\
\text { (ER- and PR-negative). } \\
\text { node-positive tumors or node-negative tumors with a } \\
\text { high risk of recurrence } \\
\text { G III } \\
\text { - young age of disease onset ( }<35 \text { years) }\end{array}$ \\
\hline $\begin{array}{l}\text { Level of evidence } \\
\mathbf{1 a}\end{array}$ & $\begin{array}{l}\text { (Cochrane: Ferguson T et al. 2007; EBCTCG 2005; EBCTCG } \\
\text { 2011; EBM Reviews 2003; NIH 2001; NZGG 2009) }\end{array}$ \\
\hline
\end{tabular}

\begin{tabular}{|c|c|}
\hline Adj-12 & Taxane-containing adjuvant standard chemotherapy \\
\hline $\begin{array}{l}\text { Grade of recom- } \\
\text { mendation } \\
\text { B }\end{array}$ & $\begin{array}{l}\text { Adjuvant chemotherapy should include a taxane. Anthra- } \\
\text { cycline- and taxane-containing adjuvant standard chemo- } \\
\text { therapy lasts } 18-24 \text { weeks. }\end{array}$ \\
\hline $\begin{array}{l}\text { Level of evidence } \\
\text { 1b }\end{array}$ & $\begin{array}{l}\text { (Bria E et al. 2006; Citron ML et al. 2003; Clavarezza M et al. } \\
\text { 2006; Cochrane: Ferguson T et al. 2007; Estevez LG et al. } \\
\text { 2007; Henderson IC et al. 2003; Mamounas EP et al. 2005; } \\
\text { Roche H et al. 2006) }\end{array}$ \\
\hline
\end{tabular}

\subsubsection{Neoadjuvant (primary systemic) therapy (NACT or PST)}

Adj-13 Neoadjuvant systemic therapy

Neoadjuvant (primary, preoperative) systemic therapy is
now deemed the standard treatment for patients with lo-
cally advanced, primarily inoperable or inflammatory
breast carcinoma within the context of a multimodal thera-
peutic strategy.
(Brito RA et al. 2001; Fisher B et al. 1997; Kaufmann M et al.
2006; von Minckwitz G et al. 2011)

\begin{tabular}{|c|c|}
\hline Adj-14 & Neoadjuvant or adjuvant chemotherapy \\
\hline $\begin{array}{l}\text { Grade of recom- } \\
\text { mendation } \\
\mathbf{0}\end{array}$ & $\begin{array}{l}\text { a. If chemotherapy is indicated, this can be undertaken } \\
\text { preoperatively (neoadjuvant) or postoperatively (adju- } \\
\text { vant). The two procedures are equivalent in terms of } \\
\text { overall survival. } \\
\text { Neoadjuvant therapy can result in a higher rate of breast- } \\
\text { conserving treatments. }\end{array}$ \\
\hline \multirow[t]{2}{*}{$\begin{array}{l}\text { Level of evidence } \\
\text { 1a }\end{array}$} & (Kaufmann M et al. 2006; von Minckwitz G et al. 2011) \\
\hline & $\begin{array}{l}\text { b. The effect is greatest on hormone receptor-negative } \\
\text { carcinomas. }\end{array}$ \\
\hline \multirow[t]{2}{*}{$\begin{array}{l}\text { Level of evidence } \\
\text { 1a }\end{array}$} & $\begin{array}{l}\text { (Bear HD et al. 2006; von Minckwitz G et al. 2005; von Min- } \\
\text { ckwitz G et al. 2011) }\end{array}$ \\
\hline & $\begin{array}{l}\text { c. Resection within the new tumor margins is possible if RO } \\
\text { resection with a sufficient safety distance can be } \\
\text { achieved. }\end{array}$ \\
\hline $\begin{array}{l}\text { Level of evidence } \\
\text { 1a }\end{array}$ & (Kaufmann M et al. 2003; von Minckwitz G et al. 2011) \\
\hline
\end{tabular}

\begin{tabular}{|c|c|}
\hline \multirow[t]{2}{*}{ Adj-15 } & $\begin{array}{l}\text { Primary hormonal therapy in postmenopausal pa- } \\
\text { tients }\end{array}$ \\
\hline & $\begin{array}{l}\text { Primary hormonal therapy represents an option for post- } \\
\text { menopausal patients with receptor-positive and HER2- } \\
\text { negative tumors in cases where surgery is contraindicated } \\
\text { or refused. }\end{array}$ \\
\hline GCP & \\
\hline
\end{tabular}

Adj-16 Neoadjuvant chemotherapeutic combination
If a chemotherapeutic combination is used as neoadjuvant
therapy, this should include an anthracycline and a taxane
(trastuzumab if HER2-positive). The duration of preopera-
tive therapy should be 6-8 cycles (equivalent to 18-24
weeks).
(von Minckwitz G et al. 2011)

\subsubsection{Antibody therapy}

\begin{tabular}{|c|c|}
\hline Adj-17 & Indications for antibody therapy \\
\hline $\begin{array}{l}\text { Grade of recom- } \\
\text { mendation } \\
\text { A }\end{array}$ & $\begin{array}{l}\text { a. Patients with HER2-overexpressing tumors with a diam- } \\
\text { eter } \geq 1 \mathrm{~cm} \text { (immunohistochemical score } 3+\text { and/or ISH- } \\
\text { positive) should receive (neo-)adjuvant treatment with } \\
\text { trastuzumab for one year. }\end{array}$ \\
\hline $\begin{array}{l}\text { Level of evidence } \\
\mathbf{1 b}\end{array}$ & (NICE 2009; NZGG 2009) \\
\hline $\begin{array}{l}\text { Grade of recom- } \\
\text { mendation } \\
\text { B }\end{array}$ & $\begin{array}{l}\text { b. Adjuvant treatment with trastuzumab should preferably } \\
\text { be started simultaneously with the taxane phase of ad- } \\
\text { juvant chemotherapy. }\end{array}$ \\
\hline \multirow[t]{2}{*}{$\begin{array}{l}\text { Level of evidence } \\
2 \mathbf{a}\end{array}$} & (Petrelli F et al. 2011) \\
\hline & $\begin{array}{l}\text { c. If there is an indication for chemotherapy in tumors } \\
<10 \mathrm{~mm} \text {, trastuzumab should be given additionally. }\end{array}$ \\
\hline
\end{tabular}

\subsubsection{Bisphosphonates}

(no statements)

\section{Recurrent or Metastatic Breast Cancer}

\subsection{Definition and prognosis} (no statements)

\subsection{Diagnostic procedures for local or locoregional recurrence}

(no statements) 


\subsection{Treatment of local/locoregional recurrence}

5.3.1 Local (in-breast) recurrence

\begin{tabular}{|c|c|}
\hline Rec-1 & Local (in-breast) recurrence \\
\hline & $\begin{array}{l}\text { a. In patients with an in-breast recurrence (DCIS or invasive } \\
\text { carcinoma), the best local tumor control is achieved by } \\
\text { secondary mastectomy. }\end{array}$ \\
\hline GCP & (Borner M et al. 1994; Dalberg K et al. 1998) \\
\hline $\begin{array}{l}\text { Grade of recom- } \\
\text { mendation } \\
\mathbf{0}\end{array}$ & $\begin{array}{l}\text { b. In patients with a favorable baseline situation, e.g. pa- } \\
\text { tients with DCIS or invasive carcinoma with a long recur- } \\
\text { rence-free interval and no skin involvement, an organ- } \\
\text { conserving surgical procedure can be performed in } \\
\text { cases where this is deemed justified. }\end{array}$ \\
\hline \multirow[t]{2}{*}{$\begin{array}{l}\text { Level of evidence } \\
\mathbf{4 a}\end{array}$} & $\begin{array}{l}\text { (Deutsch M 2002; Haffty BG et al. 1996; Kurtz JM et al. } \\
\text { 1991; Whelan T et al. 1994) }\end{array}$ \\
\hline & $\begin{array}{l}\text { c. The possibility of re-irradiation (partial breast irradiation) } \\
\text { must be investigated in the case of breast-conserving } \\
\text { surgery. }\end{array}$ \\
\hline \multicolumn{2}{|l|}{ GCP } \\
\hline & $\begin{array}{l}\text { d. Patients who undergo organ-conserving surgery must } \\
\text { be advised of the higher risk of a repeat in-breast recur- } \\
\text { rence. }\end{array}$ \\
\hline
\end{tabular}

\subsubsection{Local recurrence after mastectomy}

Rec-2 Local recurrence after mastectomy
An isolated recurrence in the chest wall should be removed
completely by surgery (R0) where possible.
(Schmoor C et al. 2000)

\subsubsection{Locoregional recurrences and isolated supracla-} vicular lymph node recurrences

Rec-3 Isolated regional recurrence
In patients with an isolated regional recurrence, the aim
should be to achieve local control of the disease by surgery
and/or radiotherapy.

\subsubsection{Pharmacotherapy}

Rec-4 Postoperative systemic therapy
The value of postoperative systemic therapy following sur-
gical resection of a locoregional recurrence in terms of im-
proved overall survival has not been sufficiently substanti-
ated. There is evidence that the disease-free interval can be
prolonged by systemic therapy.
(Cochrane: Rauschecker H et al. 2001; Cochrane: Rau-
schecker HHF et al. 2008; Haffty BG et al. 1996)

\subsubsection{Radiotherapy}

Rec-5 Radiotherapy after surgery for recurrence
a. The need for radiotherapy after surgery for a recurrence
should be discussed and decided upon within an inter-
disciplinary team. Postoperative radiotherapy can be
performed if radiotherapy was not administered previ-
ously or radical surgical excision of the local recurrence
was not performed (R1-2).

\subsection{Distant metastases \\ 5.4.1 General principles}

Met-1 Patient briefing on therapeutic options
A patient with demonstrated distant metastases of breast
cancer should be briefed in particular detail about the ther-
apeutic options and involved in the decision-making pro-
cess. The patient's request for information about all the
relevant available measures, including supportive and
complementary treatment options, should be satisfied.
(NICE 2009)

\section{Met-2 Criteria of choice of treatment}

The choice of treatment should be adapted to the disease and individually tailored to the patient's expectations, values and preferences, as well as her symptoms, comorbidities, age and general state of health, the aggressiveness of the disease and location of the metastases, the type of prior adjuvant and palliative treatment, HER-2 status, hormonereceptor status and menopausal status.

GCP

Met-3 Prognostic and predictive factors

Grade of recom- The following prognostic and predictive factors should be mendation determined before instituting treatment of metastatic A breast cancer:

- hormone receptor status for hormonal therapy

- HER-2 status for treatment with anti-HER2 active substances

- bone metastases for the administration of bisphosphonates, or where applicable a RANK ligand inhibitor

- the previous response to chemoendocrine therapy for further systemic and local therapies

- the performance status for the effect and usefulness of chemotherapy

Level of evidence (Andersson M et al. 1999; Cheung KL et al. 1997; Hortoba1a gyi GN et al. 1996; NICE 2009)

\subsubsection{Diagnostic procedures in patients with distant metastases \\ (no statements)}

\subsubsection{Systemic therapy of metastatic breast cancer \\ 5.4.3.1 Systemic endocrine therapy}

\section{Met-4 Systemic endocrine therapy}

Grade of recom- Endocrine therapy is the treatment of choice for patients mendation with a positive hormone receptor status.

A

Level of evidence (Fossati R et al. 1998; NICE 2009; Stockler M et al. 1997; 1b Stockler M et al. 2000) 


\begin{tabular}{|ll}
$\begin{array}{l}\text { Met-6 } \\
\text { Grade of recom- } \\
\text { mendation }\end{array}$ & $\begin{array}{l}\text { Combined chemoendocrine therapy } \\
\text { Combined chemoendocrine therapy is not recommended. } \\
\text { Although it can improve remission rates, it causes increased } \\
\text { toxicity without prolonging either the progression-free in- } \\
\text { terval or overall survival. }\end{array}$ \\
\hline $\begin{array}{l}\text { Level of evidence } \\
\text { 1a }\end{array}$ & \begin{tabular}{l} 
Cochrane: Carrick S et al. 2005; Sledge Jr. GW et al. 2000) \\
\hline
\end{tabular}
\end{tabular}

\subsubsection{Endocrine therapy in premenopausal patients}

\begin{tabular}{ll} 
Met-7 & $\begin{array}{l}\text { Ovarian suppression and tamoxifen in premenopau- } \\
\text { sal patients }\end{array}$ \\
$\begin{array}{l}\text { Grade of recom- } \\
\text { mendation }\end{array}$ & $\begin{array}{l}\text { Suppression of ovarian function (GnRH analogs, oophorec- } \\
\text { tomy, and ovarian ablation by radiotherapy) in combination } \\
\text { with tamoxifen is the first-choice therapy in premenopausal } \\
\text { A }\end{array}$ \\
$\begin{array}{l}\text { patients. } \\
\text { Level of evidence } \\
\text { 1b }\end{array}$ & Klijn JG et al. 2001; NBOCC2010; NICE 2009) \\
\hline
\end{tabular}

\begin{tabular}{ll}
$\begin{array}{ll}\text { Met-8 } & \text { Other treatments in premenopausal patients } \\
\text { Grade of recom- } \\
\text { mendation }\end{array}$ & $\begin{array}{l}\text { In premenopausal patients, ovarian suppression can be } \\
\text { used subsequently in combination with an aromatase in- } \\
\text { hibitor. Treatment with high-dose progestins (MA/MPA) } \\
\text { represents a further step. }\end{array}$ \\
\hline $\begin{array}{l}\text { Level of evidence } \\
\text { (NICE 2009; Taylor CW et al. 1998; von Minckwitz G et al. }\end{array}$ \\
\hline 1991)
\end{tabular}

\subsubsection{Endocrine therapy in postmenopausal patients}

$\begin{array}{ll}\begin{array}{l}\text { Met-9 } \\ \text { Grade of recom- } \\ \text { mendation }\end{array} & \begin{array}{l}\text { Aromatase inhibitors in postmenopausal patients } \\ \text { In postmenopausal patients with metastases, the first step } \\ \text { in endocrine treatment following adjuvant therapy with ta- } \\ \text { moxifen or no adjuvant endocrine therapy is the adminis- } \\ \text { tration of an aromatase inhibitor. }\end{array} \\ \begin{array}{ll}\text { Level of evidence } & \text { (Cochrane: Cibson L et al. 2009; Ellis MJ et al. 2000; Fossati R } \\ \text { 1a } & \text { et al. 1998; Hayes DF et al. 1995; Mouridsen H et al. 2001a; } \\ & \text { Mouridsen H et al. 2001b; NICE 2009) }\end{array}\end{array}$

Met-10 Treatment cascade in postmenopausal patients
Depending on the prior treatment, further steps in the cas-
cade of endocrine therapy in postmenopausal women are
the administration of antiestrogens, estrogen receptor an-
tagonists, switch from a steroidal to a non-steroidal aroma-
tase inhibitor (or vice versa), or the use of high-dose pro-
gestins.
GCP
(Fossati R et al. 1998; Robertson JF et al. 2003)

\subsubsection{Chemotherapy of metastatic breast cancer}

Met-11 Criteria for chemotherapy
The patient's general condition and comorbidities must be
established and compliance must be assessed before che-
motherapy is administered.

\section{Met-12 Assessment of toxicity}

Toxicity must be assessed both objectively and subjectively at regular intervals during therapy. The doses administered, as well as the intended time intervals, must conform to generally accepted standard or currently published therapeutic regimens. After a suitable and representative measurement parameter has been selected prior to the institution of therapy (e.g., symptoms, tumor markers, indicator metastasis), the therapeutic effect should be evaluated at least every 612 weeks, depending on the clinical requirements/studies. Cytotoxic maintenance therapy increases toxicity without improving survival. For this reason, cytotoxic therapy is recommended only in the event of progression (increased symptoms and/or progression of the tumor process).

GCP

Met-13 End of chemotherapy
Treatment should be stopped immediately if progression or
intolerable toxicity occurs.

\begin{tabular}{|c|c|}
\hline Met-14 & Combination chemotherapy \\
\hline & $\begin{array}{l}\text { a. The administration of combination, as opposed to sin- } \\
\text { gle-agent, chemotherapy may confer a slight advantage } \\
\text { in terms of survival, but is often associated with a higher } \\
\text { rate of toxicity. }\end{array}$ \\
\hline $\begin{array}{l}\text { Level of evidence } \\
\text { 1a }\end{array}$ & $\begin{array}{l}\text { (Cochrane: Carrick S et al. 2005; Cochrane: Carrick S et al. } \\
\text { 2009; Fossati R et al. 1998) }\end{array}$ \\
\hline $\begin{array}{l}\text { Grade of recom- } \\
\text { mendation } \\
\text { B }\end{array}$ & $\begin{array}{l}\text { b. In patients with mild symptoms and slow tumor growth, } \\
\text { as well as cases where endocrine therapy is ineffective, } \\
\text { single-agent chemotherapy is useful. } \\
\text { In patients with severe symptoms and rapidly growing or } \\
\text { aggressive tumors (i.e. where there is a strong pressure to } \\
\text { achieve remission), combination chemotherapy should be } \\
\text { administered. }\end{array}$ \\
\hline Level of evidence & (Cochrane: Carrick S et al. 2005; Fossati R et al. 1998) \\
\hline
\end{tabular}

\section{Met-15 Monotherapy}

The following substances, for example, may be used for single-agent chemotherapy: Anthracyclines (including those in liposomal form), alkylating agents, anthraquinones, taxanes, vinorelbine fluoropyrimidine, platinum complexes and halichondrin. In combination chemotherapy, these cytotoxic agents can be combined with each other or with other substances. The highest remission rates are achieved with a taxane in combination with an anthracycline or antimetabolite.

Patients should be checked to see whether they are eligible for inclusion in studies. (Cochrane: Carrick S et al. 2005; Fossati R et al. 1998)

$\begin{array}{ll}\begin{array}{l}\text { Met-16 } \\ \text { Grade of recom- } \\ \text { mendation }\end{array} & \begin{array}{l}\text { Further chemotherapies } \\ \text { After the benefits of anthracycline and taxane treatments } \\ \text { Bave been exhausted, patients should not be denied further } \\ \text { Bemotherapies, e.g., to stabilize the disease or alleviate } \\ \text { symptoms. }\end{array} \\ \begin{array}{ll}\text { Level of evidence } \\ \text { 2b }\end{array} & \text { (Feher O et al. 2002; NBOCC2010; Vogel C et al. 1999) }\end{array}$

\begin{tabular}{|c|c|}
\hline Met-17 & Dose-intensified and high-dose therapies \\
\hline $\begin{array}{l}\text { Grade of recom- } \\
\text { mendation } \\
\text { A }\end{array}$ & $\begin{array}{l}\text { Dose-intensified and high-dose therapies do not exhibit any } \\
\text { improvement in survival and should therefore not be used. }\end{array}$ \\
\hline $\begin{array}{l}\text { Level of evidence } \\
\text { 1b }\end{array}$ & $\begin{array}{l}\text { (Cochrane: Farquhar C et al. 2005; Stadtmauer EA et al. } \\
\text { 2000) }\end{array}$ \\
\hline
\end{tabular}




\subsubsection{Targeted therapies}

5.4.5.1 HER2 inhibitors (trastuzumab, lapatinib)

Met-18 Hormone receptor status and HER2 status
The histology of the suspected metastatic lesion should be
determined in advance of any therapy, if possible, to reas-
sess the benign or malignant nature of the tumor and,
where applicable, the hormone receptor and HER2 status.
GCP

\begin{tabular}{|l|l|}
\hline Met-19 & $\begin{array}{l}\text { Anti-HER2 therapy } \\
\text { a. Treatment with HER-2 inhibitors is indicated in patients } \\
\text { with HER-2-overexpressing tumors in combination with } \\
\text { chemotherapy, or after remission induction as single- } \\
\text { agent therapy, or after previous treatment with taxanes } \\
\text { or anthracyclines with a non-cross-resistant chemother- } \\
\text { apeutic agent. }\end{array}$ \\
& $\begin{array}{l}\text { (Burstein HJ et al. 2001; NBOCC2010; Seidman AD et al. } \\
\text { 2001; Slamon DJ et al. 2001) }\end{array}$ \\
\hline GCP & $\begin{array}{l}\text { b. Any secondary therapy following progression during } \\
\text { trastuzumab therapy should continue to include anti- } \\
\text { HER2-directed therapy. }\end{array}$ \\
\hline Level of evidence & (NBOCC2010) \\
\hline $\mathbf{2 b}$ &
\end{tabular}

Met-20 Monitoring of cardiac function
It is essential to monitor cardiac function before and during
therapy with potentially cardiotoxic substances.

\subsubsection{Antiangiogenesis: VEGF inhibitors (bevacizumab)}

Met-21 Use of bevacizumab
In patients with metastatic breast cancer receiving pacli-
taxel or capecitabine as first-line cytostatic therapy, bevaci-
zumab can be administered additionally to improve the
therapeutic outcome.

\subsubsection{Specific treatment of skeletal metastases \\ 5.4.6.1 Indications for radiotherapy}

\begin{tabular}{|c|c|}
\hline Met-22 & Indications for radiotherapy \\
\hline $\begin{array}{l}\text { Grade of recom- } \\
\text { mendation } \\
\text { A }\end{array}$ & $\begin{array}{l}\text { Radiotherapy should be used for local therapy in patients } \\
\text { with symptomatic bone metastases, or those posing a risk } \\
\text { of fracture. The following constitute indications for radio- } \\
\text { therapy: } \\
\text { - local pain symptoms } \\
\text { - risk to stability (if necessary in combination with surgical } \\
\text { stabilization) } \\
\text { - impairment of mobility and/or function, in particular } \\
\text { neurological symptoms (spinal cord compression is an } \\
\text { emergency) } \\
\text { pathological fractures that cannot be surgically treated } \\
\text { postoperatively following the surgical treatment of bone } \\
\text { metastases if R0 resection was not possible }\end{array}$ \\
\hline $\begin{array}{l}\text { Level of evidence } \\
\text { 1a }\end{array}$ & $\begin{array}{l}\text { (Hoskin PJ et al. 2001; NICE 2009; Roos DE et al. 2000; } \\
\text { Steenland E et al. 1999) }\end{array}$ \\
\hline
\end{tabular}

\subsubsection{Surgical therapy}

Met-23 Surgical therapy
Surgical therapy of skeletal metastases is undertaken for
pain management and to restore or preserve function and
stability, as well as quality of life. The decision to operate is
made on the basis of the urgency and the therapeutic ob-
jective of this surgery, where necessary by an interdiscipli-
nary team including the surgeon (general surgeon, ortho-
pedic surgeon or neurosurgeon), radiation oncologist,
medical specialist with oncological expertise, and pain
therapist.
GCP

\section{Met-24 Indications for surgical therapy}

The following constitute indications for surgical therapy:

- pathological fractures (especially in the lower extremities and the acetabulum)

- unstable pathological vertebral fractures

- progressive spinal or radicular compression (the option of radiotherapy should be considered)

- impending fractures of the lower extremities

GCP (Ali SM et al. 2003; Brown JE et al. 2003; Clohisy DR 2003; Fourney DE et al. 2003; Kelly CM et al. 2003; Koizumi M et al. 2003; Walker MP et al. 2003; Wunder JS et al. 2003)

\subsubsection{Bisphosphonates/RANK ligand inhibitor therapy}

Met-25

GCP

\subsubsection{Specific treatment of brain metastases}

\begin{tabular}{|c|c|}
\hline Met-26 & Treatment of brain metastases \\
\hline $\begin{array}{l}\text { Grade of recom- } \\
\text { mendation } \\
\mathbf{0}\end{array}$ & $\begin{array}{l}\text { An isolated brain metastasis can be treated by surgery, by } \\
\text { single-session stereotactic irradiation (RS), or by fraction- } \\
\text { ated radiotherapy (SFRT), especially if the extracerebral } \\
\text { disease is under control. }\end{array}$ \\
\hline $\begin{array}{l}\text { Level of evidence } \\
2 \mathbf{a}\end{array}$ & (NICE 2009) \\
\hline
\end{tabular}

\begin{tabular}{|c|c|}
\hline Met-27 & Multiple brain metastases \\
\hline $\begin{array}{l}\text { Grade of recom- } \\
\text { mendation } \\
\text { A }\end{array}$ & $\begin{array}{l}\text { In patients with multiple brain metastases, percutaneous } \\
\text { irradiation of the entire cranium (whole brain radiothera- } \\
\text { py), supported by steroid medication in patients with peri- } \\
\text { focal edema, is indicated for the control of existing neuro- } \\
\text { logical symptoms. }\end{array}$ \\
\hline $\begin{array}{l}\text { Level of evidence } \\
\mathbf{2 a}\end{array}$ & (Cochrane: Hart MG et al. 2004; Kondziolka D et al. 1999) \\
\hline
\end{tabular}




\subsubsection{Special treatments of visceral metastases}

Met-28 Treatment of visceral metastases
In individual cases that satisfy the following criteria, local
therapy may be indicated for patients with visceral metas-
tases (liver, lungs or other organs):

$\quad$ no disseminated metastases
metastases in only one lobe of the lungs or liver; if both
lobes are affected, surgery is not indicated
$\quad$ the metastasis did not occur during the first year after
$\quad$ primary treatment.
GCP $\quad$ (Bathe OF et al. 1999; Vogl TJ et al. 1999)

\subsubsection{Hepatic metastases}

(no statements)

5.4.7.2 Pulmonary metastases

(no statements)

\subsubsection{Malignant pleural effusion}

$\begin{array}{ll}\text { Met-29 } & \text { Malignant pleural effusion } \\ & \begin{array}{l}\text { In cases where pleural carcinosis occurs with symptomatic } \\ \text { effusion, pleurodesis may be indicated. }\end{array} \\ \text { GCP } & \text { (Cardillo G et al. 2002) }\end{array}$

\subsubsection{Cutaneous and soft tissue metastases \\ (no statements)}

\section{Treatment, Care and Support}

\subsection{General concept}

(no statements)

\subsection{Psychosocial aspects and psycho-oncology}

\subsubsection{Basic principles of psycho-oncological care}

\begin{tabular}{|c|c|}
\hline Psych-1 & Psycho-oncological assistance \\
\hline & $\begin{array}{l}\text { a. Psycho-oncological measures are an integral part of the } \\
\text { overall strategy of cancer therapy. }\end{array}$ \\
\hline $\begin{array}{l}\text { Level of evidence } \\
\mathbf{1 b}\end{array}$ & $\begin{array}{l}\text { (Cochrane: Edwards AG et al. 2004; NICE 2009b; Sheard T et } \\
\text { al. 1999) }\end{array}$ \\
\hline $\begin{array}{l}\text { Grade of recom- } \\
\text { mendation } \\
\text { A }\end{array}$ & $\begin{array}{l}\text { b. All patients and their relatives should be informed at an } \\
\text { early stage of the possibilities of psycho-oncological as- } \\
\text { sistance. }\end{array}$ \\
\hline $\begin{array}{l}\text { Level of evidence } \\
\mathbf{1 b}\end{array}$ & (NICE 2009b) \\
\hline
\end{tabular}

\subsubsection{Psycho-oncological care strategies} and interventions

$\begin{array}{ll}\text { Psych-2 } & \text { Psycho-oncological interventions } \\ \text { Grade of recom- } & \text { The following psycho-oncological interventions should be } \\ \text { mendation } & \text { offered, tailored to the patients' individual requirement: } \\ \text { A } & \text { relaxation techniques } \\ & \text { psychoeducative interventions } \\ & \text { individual psychotherapeutic interventions } \\ & \text { group psychotherapeutic interventions } \\ \text { Level of evidence } & \text { (Faller Het al. Metaanalysis in press) } \\ \text { 1a } & \end{array}$

Psych-3

$\begin{array}{ll}\begin{array}{l}\text { Psych-4 } \\ \begin{array}{l}\text { Grade of recom- } \\ \text { mendation }\end{array}\end{array} & \begin{array}{l}\text { Recommendation } \\ \text { The patient's quality of life should be assessed regularly in } \\ \text { the course of the disease. }\end{array} \\ \begin{array}{ll}\text { Level of evidence } \\ \text { 2a }\end{array} & \begin{array}{l}\text { (Lemieux J et al. 2011; Velikova G et al. 1999; Velikova G } \\ \text { et al. 2004) }\end{array}\end{array}$

\subsection{Supportive therapy}

$\begin{array}{ll}\begin{array}{l}\text { Supp-1 } \\ \text { Grade of recom- } \\ \text { mendation }\end{array} & \begin{array}{l}\text { Physical activity } \\ \text { The patient should be made aware of the need for physical } \\ \text { activity during chemotherapy and radiotherapy, as this can } \\ \text { have a positive effect on patients' physical fitness and thus } \\ \text { help them to carry out activities of daily living (ADL). }\end{array} \\ \begin{array}{ll}\text { Level of evidence } \\ \text { 1a }\end{array} & \begin{array}{l}\text { (Cochrane: Markes M et al. 2006) } \\ \end{array}\end{array}$

\subsection{Rehabilitation}

\section{Rehab-1 Rehabilitation measures}

The tumor and its treatment by surgery, radiotherapy and systemic therapy can cause sequelae of varying degrees of severity that require targeted somatic and psychosocial rehabilitation measures. Patients should be informed at an early stage about the options for outpatient and inpatient rehabilitation measures and about additional claims arising under German social law. The patient's preferences should be taken into consideration when establishing the need for, and recommending, a particular type of rehabilitation.

GCP $\quad$ (DRV Bund 2009)

\section{Rehab-2 Strength and endurance training \\ Strength training, alone or in combination with endurance training, in the rehabilitation phase is a suitable way of im- proving the state of health and quality of life. \\ Level of evidence (Cheema B et al. 2008) \\ 1 a}

Rehab-3 Movement programs

Movement programs are suitable for reducing fatigue (tiredness) due to cancer.

Level of evidence (Cochrane: Cramp F et al. 2008)

1a

\section{Rehab-4 Physiotherapy}

Grade of recom- Postoperative physiotherapy to mobilize the shoulder joint mendation should start at an early stage.

A

Level of evidence (Chan DN et al. 2010; Cochrane: McNeely ML et al. 2010) 1a

\section{Rehab-5 Lymphedema}

In patients with lymphedema, combined physiotherapy (skin care, manual lymph drainage, movement therapy, and compression bandages) is a suitable treatment method. 


\subsection{Follow-up care including diagnostic workup of recurrences and metastases and support during therapy \\ 6.5.1 Objectives}

\begin{tabular}{|l|l|} 
FU-1 & Follow-up care for breast cancer \\
& Follow-up care for breast cancer begins when locoregional \\
primary treatment is completed. It consists of history- \\
taking, a physical examination, medical advice, support and \\
continuing care, as well as diagnostic imaging procedures \\
to detect locoregional recurrences. \\
In the event of abnormal findings, follow-up care should be \\
designed so as to be symptom-oriented. \\
(Cochrane: Rojas MP et al. 2005; Grunfeld E et al. 2005; \\
Gulliford T et al. 1997; Hurria A et al. 2003; Khatcheressian \\
JL et al. 2006; NBOCC2010; Palli D et al. 1999; Pestalozzi BC \\
et al. 2005; Rosselli DT et al. 1994)
\end{tabular}

\section{FU-2 Interdisciplinary support and continuing care}

As part of her follow-up care, the breast cancer patient requires intensive interdisciplinary support and continuing care. Oncology specialists and also other healthcare professionals such as psycho-oncologists, physiotherapists, oncological nursing staff, breast care nurses, etc., should be involved as needed. The patient should be given information appropriate to her individual needs about the options for further treatment and support. (NBOCC2010; Selby P et al. 1996)

\subsubsection{Examinations to detect locoregional and in-breast recurrences, or contralateral breast cancer}

FU-3 Instrumental diagnostic procedures after BCT
In asymptomatic women who have undergone breast-con-
serving therapy, regular instrumental diagnostic proce-
dures (mammography and ultrasonography) in the area of
the ipsilateral breast are indispensable.

$\begin{array}{ll}\text { FU-4 Follow-up mammograms } & \begin{array}{l}\text { All patients should undergo annual follow-up mammo- } \\ \text { grams (where necessary supplemented by ultrasonogra- } \\ \text { phy) of the contralateral breast. }\end{array} \\ & \text { (Geller BM et al. 2003; Johnson RC et al. 2000; Jubelirer SJ } \\ \text { 1998; Kollias J et al. 2000) }\end{array}$

\subsubsection{Examination for metastases}

\begin{tabular}{|c|c|}
\hline FU-5 & $\begin{array}{l}\text { Intensified instrumental and technical laboratory } \\
\text { diagnostic procedures }\end{array}$ \\
\hline $\begin{array}{l}\text { Grade of recom- } \\
\text { mendation }\end{array}$ & $\begin{array}{l}\text { Intensified instrumental and technical laboratory diagnos- } \\
\text { tic procedures, including chest } \mathrm{X} \text {-ray, bone scan, } \mathrm{CT} \text {, PET or }\end{array}$ \\
\hline A & $\begin{array}{l}\text { MRI, as well as blood counts, serum biochemistry or tumor } \\
\text { marker determination, are used for the diagnostic workup } \\
\text { of metastases and not for standard follow-up care, and are } \\
\text { only indicated in the event of clinical abnormalities. }\end{array}$ \\
\hline $\begin{array}{l}\text { Level of evidence } \\
\text { 1a }\end{array}$ & $\begin{array}{l}\text { (Aguiar-Bujanda D et al. 2004; Bornhak S et al. 2007; Co- } \\
\text { chrane: Rojas MP et al. 2000; Cochrane: Rojas MP et al. } \\
\text { 2005; GIVIO Investigators 1994; Hayes DF 2007; } \\
\text { NBOCC2010) }\end{array}$ \\
\hline
\end{tabular}

\subsubsection{Diagnostic workup and treatment of side effects and sequelae of primary and long-term treatments}

\begin{tabular}{|c|c|}
\hline FU-6 & Briefing about lymphedema \\
\hline $\begin{array}{l}\text { Grade of recom- } \\
\text { mendation } \\
\text { A }\end{array}$ & $\begin{array}{l}\text { All patients who have undergone axillary lymphadenecto- } \\
\text { my must be briefed about the options for detection, pro- } \\
\text { phylaxis and treatment of postoperative lymphedema. }\end{array}$ \\
\hline $\begin{array}{l}\text { Level of evidence } \\
\mathbf{1 b}\end{array}$ & $\begin{array}{l}\text { (Armer J et al. 2004; Bani HA et al. 2007; Francis WP et al. } \\
\text { 2006; Golshan M et al. 2003; Hamner JB et al. 2007; Harris } \\
\text { SR et al. 2001; Hayes S et al. 2005; Moseley AL et al. 2007; } \\
\text { NICE 2009; Sanjuan A et al. 2005; Torrenga H et al. 2004) }\end{array}$ \\
\hline
\end{tabular}

\subsubsection{Frequency of follow-up examinations}

\section{FU-7 Follow-up intervals}

Follow-up visits should be scheduled four times a year during the first three years after local primary therapy, twice a year during the fourth and fifth years, and annually from the sixth year onwards. These visits should incorporate screening for early detection.

GCP (Khatcheressian JL et al. 2006)

$\begin{array}{ll}\text { FU-8 } & \text { Physical activity } \\ & \text { Patients should be encouraged to undertake physical activ- } \\ & \text { ity ( }>2-3 \text { hours/week) and to normalize their bodyweight } \\ \text { (if they have an increased BMI) as part of their follow-up } & \\ \text { care. Assistance should be provided. } \\ \text { (Grunfeld Ee et al. 2005; Hauner D. et al. 2011; Voskuil DWet } \\ \text { al. 2010) }\end{array}$

\section{FU-9 Patient motivation}

An essential part of follow-up care is the constant motivation of the patient to regularly take the medications prescribed for adjuvant therapy, particularly endocrine therapy (e.g., tamoxifen or aromatase inhibitors).

The patient should be questioned in detail about tolerability and/or side effects. Appropriate measures must be used to treat the symptoms.

GCP

\subsection{Palliative medicine}

\section{Pall-1 Palliative medicine measures}

Palliative medical measures are part of the overall strategy of oncological care.

GCP

\section{Pall-2 Briefing of the patient and her relatives}

The patient and her relatives should be informed about the possibilities of palliative medical measures and care structures. 


\subsection{Complementary therapy}

Compl-1 Complementary and alternative therapies
All patients should be asked whether they employ comple-
mentary and/or alternative therapies. Patients who use
such procedures should be briefed about the possible risks
and, where applicable, about interactions with standard
treatments.

\subsubsection{Diagnostic workup}

Compl-2 Diagnostic measures for complementary treatment
strategies
The diagnostic measures based on scientifically unproven
concepts and/or incorrect interpretations of the relation-
ships between the different functions of the body that are
offered in conjunction with complementary and alternative
treatment strategies should not be recommended.

$\begin{array}{ll}\text { Compl-3 } & \text { Food supplements } \\ & \text { During chemotherapy, hormone therapy, or radiotherapy, } \\ \text { food supplements such as vitamins and trace elements } \\ \text { should be supplied, where possible, through the natural } \\ \text { diet and according to physiological requirements. }\end{array}$

\subsubsection{Mistletoe therapy}

\begin{tabular}{|c|c|}
\hline \multirow[t]{2}{*}{ Compl-4 } & Mistletoe therapy \\
\hline & $\begin{array}{l}\text { Mistletoe therapy does not prolong the survival of patients } \\
\text { with breast cancer and an improvement in the quality of life } \\
\text { is doubtful on the basis of current data. }\end{array}$ \\
\hline $\begin{array}{l}\text { Level of evidence } \\
\text { 1a }\end{array}$ & (Cochrane: Horneber MA et al. 2008) \\
\hline
\end{tabular}

\subsubsection{Traditional Chinese medicine (TCM)} (no statements)

\subsubsection{Cimicifuga (black cohosh)}

(no statements)

\subsubsection{Homeopathy}

(no statements)

\subsubsection{Meditation and mindfulness-based stress reduction \\ (no statements)}

\subsubsection{Alternative methods}

Compl-5 Alternative treatment procedures
Alternative treatment procedures should not be recom-
mended to patients. In a sympathetic counseling situation,
the patient should be informed about the harm and benefit
of this treatment in a value-neutral, competent and com-
prehensive way.

\subsection{Documentation}

Docu-1 Documentation of findings, treatments and out-
comes
Findings, treatments, both primary and during the course
of the disease, and relevant outcome events should be
documented by hospitals, office-based physicians, and in-
stitutes responsible for care, used as needed at any time,
and analyzed regularly.

\section{Affiliations}

${ }^{1}$ Landshut

2 Universitätsklinikum Gießen und Marburg GmbH, Standort Marburg, Klinik für Gynäkologie, Gynäkologische Endokrinologie und Onkologie, Marburg

${ }^{3}$ Deutsche Krebsgesellschaft e. V., Bereich Leitlinien, Berlin

${ }^{4}$ AWMF-Institut für Medizinisches Wissensmanagement, c/o Philipps-

Universität, Marburg

${ }^{5}$ Klinikum Esslingen, Klinik für Frauenheilkunde und Geburtshilfe, Esslingen

${ }^{6}$ Universitätsklinikum Ulm, Klinik für Frauenheilkunde und Geburtshilfe, Ulm

\section{References}

1 Aberizk WJ, Silver B, Henderson IC et al. The use of radiotherapy for treatment of isolated locoregional recurrence of breast carcinoma after mastectomy. Cancer 1986; 58: 1214-1218

2 Aguiar-Bujanda D, Bohn-Sarmiento U, Aguiar-Morales J. False elevation of serum CA 15-3 levels in patients under follow-up for breast cancer. Breast J 2004; 10: 375-376

$3 \mathrm{Ahn} P H, V u H T$, Lannin D et al. Sequence of radiotherapy with tamoxifen in conservatively managed breast cancer does not affect local relapse rates. J Clin Oncol 2005; 23: 17-23

4 Albert US, Schulz K, Alt D et al. Eine Leitlinie für Leitlinien: methodische Erstellung und Anwendung der Leitlinie Fraueninformation. Zentralbl Gynaekol 2003; 125: 484-493

5 Albert US und die Mitglieder der Planungskommission und Arbeitsgruppenleiter der Konzertierten Aktion Brustkrebs-Früherkennung in Deutschland. Stufe-3-Leitlinie Brustkrebs-Früherkennung in Deutschland, 1. Aktualisierung 2008. München: Zuckschwerdt Verlag; 2008

6 Alderson PO, Adams DF, McNeil BJ et al. Computed tomography, ultrasound, and scintigraphy of the liver in patients with colon or breast carcinoma: a prospective comparison. Radiology 1983; 149: 225-230

7 Ali SM, Harvey HA, Lipton A. Metastatic breast cancer: overview of treatment. Clin Orthop Relat Res 2003; 1 (415 Suppl.): S132-S137

8 Amendoeira I. Quality Assurance Guidelines for Pathology: Open Biopsy and Resection Specimens. In: Perry NM, ed. European Guidelines for Quality Assurance in Breast Cancer Screening and Diagnosis. Luxemburg: Office for Official Publications of the European Communities; 2006: 256-311

9 Andersson M, Madsen EL, Overgaard $M$ et al. Doxorubicin versus methotrexate both combined with cyclophosphamide, 5-fluorouracil and tamoxifen in postmenopausal patients with advanced breast cancer - a randomised study with more than 10 years follow-up from the Danish Breast Cancer Cooperative Group. Danish Breast Cancer Cooperative Group (DBCG). Eur J Cancer 1999; 35: 39-46

10 Antonini N, Jones $H$, Horiot JC et al. Effect of age and radiation dose on local control after breast conserving treatment: EORTC trial 2288110882. Radiother Oncol 2007; 82: 265-271

11 Armer J, Fu MR, Wainstock JM et al. Lymphedema following breast cancer treatment, including sentinel lymph node biopsy. Lymphology 2004; 37: 73-91

12 Azria D, Betz M, Bourgier C et al. Identifying patients at risk for late radiation-induced toxicity. Crit Rev Oncol Hematol 2012; 84 (Suppl. 1): e35-e41

13 Balduzzi A, Leonardi MC, Cardillo $A$ et al. Timing of adjuvant systemic therapy and radiotherapy after breast-conserving surgery and mastectomy. Cancer Treat Rev 2010; 36: 443-450

14 Bani HA, Fasching PA, Lux MM et al. Lymphedema in breast cancer survivors: assessment and information provision in a specialized breast unit. Patient Educ Couns 2007; 66: 311-318 
15 Bartelink H, Horiot JC, Poortmans PM et al. Impact of a higher radiation dose on local control and survival in breast-conserving therapy of early breast cancer: 10 -year results of the randomized boost versus no boost EORTC22881-10882 trial. J Clin Oncol 2007; 25: 3259-3265

16 Bathe OF, Kaklamanos IG, Moffat FL et al. Metastasectomy as a cytoreductive strategy for treatment of isolated pulmonary and hepatic metastases from breast cancer. Surg Oncol 1999; 8: 35-42

17 Baxter NN, Virnig BA, Durham SB et al. Radiation after lumpectomy for DCIS to reduce the risk of invasive breast cancer: a population-based study [Meeting Abstracts]. J Clin Oncol 2005; 23 (16 Suppl.): 516

18 Belkacemi Y, Fourquet A, Cutuli B et al. Radiotherapy for invasive breast cancer: guidelines for clinical practice from the French expert review board of Nice/Saint-Paul de Vence. Crit Rev Oncol Hematol 2011; 79: 91-102

19 Belkacemi Y, Gligorov J, Ozsahin M et al. Concurrent trastuzumab with adjuvant radiotherapy in HER2-positive breast cancer patients: acute toxicity analyses from the French multicentric study. Ann Oncol 2008; 19: $1110-1116$

20 Bermejo-Perez MJ, Marquez-Calderon S, Llanos-Mendez A. Effectiveness of preventive interventions in BRCA1/2 gene mutation carriers: a systematic review. Int J Cancer 2007; 121: 225-231

21 Bijker N, Meijnen P, Peterse JL et al. Breast-conserving treatment with or without radiotherapy in ductal carcinoma-in-situ: ten-year results of European Organisation for Research and Treatment of Cancer randomized phase III trial 10853 - a study by the EORTC Breast Cancer Cooperative Group and EORTC Radiotherapy Group. J Clin Oncol 2006; 24: 3381-3387

22 Blichert-Toft M, Smola MG, Cataliotti L et al. Principles and guidelines for surgeons - management of symptomatic breast cancer. On behalf of the European Society of Surgical Oncology. Ann Chir Gynaecol 1998; 87: 101-109

23 Bonadonna G, Zambetti M, Valagussa P. Sequential or alternating doxorubicin and CMF regimens in breast cancer with more than three positive nodes. Ten-year results. JAMA 1995; 273: 542-547

24 Borner M, Bacchi M, Goldhirsch A et al. First isolated locoregional recurrence following mastectomy for breast cancer: results of a phase III multicenter study comparing systemic treatment with observation after excision and radiation. Swiss Group for Clinical Cancer Research. J Clin Oncol 1994; 12: 2071-2077

25 Bornhak S, Heidemann E, Herschlein HJ et al. Symptom-oriented followup of early breast cancer is not inferior to conventional control. Results of a prospective multicentre study. Onkologie 2007; 30: 443-449

26 Boyages J, Delaney G, Taylor R. Predictors of local recurrence after treatment of ductal carcinoma in situ: a meta-analysis. Cancer 1999; 85 616-628

27 Bria E, Nistico C, Cuppone F et al. Benefit of taxanes as adjuvant chemotherapy for early breast cancer: pooled analysis of 15,500 patients. Cancer 2006; 106: 2337-2344

28 Brito RA, Valero $V$, Buzdar AU et al. Long-term results of combined-modality therapy for locally advanced breast cancer with ipsilateral supraclavicular metastases: The University of Texas M.D. Anderson Cancer Center experience. J Clin Oncol 2001; 19: 628-633

29 Brown JE, Coleman RE. Metastatic bone disease: developing strategies to optimize management. [DKG-R]. Am J Cancer 2003; 2: 269-281

30 Bruera E, Willey JS, Palmer JL et al. Treatment decisions for breast carcinoma: patient preferences and physician perceptions. Cancer 2002; 94: 2076-2080

31 Buchholz TA. Radiation therapy for early-stage breast cancer after breast-conserving surgery. N Engl J Med 2009; 360: 63-70

32 Buchholz TA, Lehman CD, Harris JR et al. Statement of the science concerning locoregional treatments after preoperative chemotherapy for breast cancer: a National Cancer Institute conference. J Clin Oncol 2008; 26: 791-797

33 Buchholz TA, Tucker SL, Masullo L et al. Predictors of local-regional recurrence after neoadjuvant chemotherapy and mastectomy without radiation. J Clin Oncol 2002; 20: 17-23

34 Budman DR, Berry DA, Cirrincione CT et al. Dose and dose intensity as determinants of outcome in the adjuvant treatment of breast cancer. The Cancer and Leukemia Group B. J Natl Cancer Inst 1998; 90: 12051211

35 Bundred NJ. Prognostic and predictive factors in breast cancer. Cancer Treat Rev 2001; 27: 137-142

36 Burstein HJ, Kuter I, Campos SM et al. Clinical activity of trastuzumab and vinorelbine in women with HER2-overexpressing metastatic breast cancer. J Clin Oncol 2001; 19: 2722-2730
37 Burstein HJ, Prestrud AA, Seidenfeld J et al. American Society of Clinical Oncology clinical practice guideline: update on adjuvant endocrine therapy for women with hormone receptor-positive breast cancer. J Clin Oncol 2010; 28: 3784-3796

38 Butow P, Harrison JD, Choy ET et al. Health professional and consumer views on involving breast cancer patients in the multidisciplinary discussion of their disease and treatment plan. Cancer 2007; 110: 19371944

39 Cady B, Stone MD, Wayne J. New therapeutic possibilities in primary invasive breast cancer. Ann Surg 1993; 218: 338-347

40 Calderon-Margalit $R$, Paltiel 0 . Prevention of breast cancer in women who carry BRCA1 or BRCA2 mutations: a critical review of the literature. Int J Cancer 2004; 112: 357-364

41 Cardillo G, Facciolo F, Carbone L et al. Long-term follow-up of video-assisted talc pleurodesis in malignant recurrent pleural effusions. Eur J Cardiothorac Surg 2002; 21: 302-305

42 Carlson RW, Moench SJ, Hammond ME et al. HER2 testing in breast cancer: NCCN Task Force report and recommendations. J Natl Compr Canc Netw 2006; 4 (Suppl. 3): S1-S22

43 Carter CL, Allen C, Henson DE. Relation of tumor size, lymph node status, and survival in 24,740 breast cancer cases. Cancer 1989; 63: 181 187

44 Chan DN, Lui LY, So WK. Effectiveness of exercise programmes on shoulder mobility and lymphoedema after axillary lymph node dissection for breast cancer: systematic review. J Adv Nurs 2010; 66: 19021914

45 Chargari C, Kirov KM, Bollet MA et al. Cardiac toxicity in breast cancer patients: from a fractional point of view to a global assessment. Cancer Treat Rev 2011a; 37: 321-330

46 Chargari C, Levy A, Vedrine L et al. Current trials of cytotoxic and targeted agents in breast cancer: the caveat of radiotherapy. Ann Oncol 2011b; 22: 1243-1244

47 Cheema B, Gaul CA, Lane $K$ et al. Progressive resistance training in breast cancer: a systematic review of clinical trials. Breast Cancer Res Treat 2008; 109: 9-26

48 Cheung KL, Willsher PC, Pinder SE et al. Predictors of response to second-line endocrine therapy for breast cancer. Breast Cancer Res Treat 1997; 45: 219-224

49 Christiaens M, Vlayen J, Gailly J. Scientific Support of the College of Oncology: a national clinical Practice Guideline for Breast Cancer. KCE Report 63A. Brüssel: Belgian Health Care Knowledge Centre (KCE); 2007

50 Citron ML, Berry DA, Cirrincione C et al. Randomized trial of dose-dense versus conventionally scheduled and sequential versus concurrent combination chemotherapy as postoperative adjuvant treatment of node-positive primary breast cancer: first report of Intergroup Trial C9741/Cancer and Leukemia Group B Trial 9741. J Clin Oncol 2003; 21: $1431-1439$

51 Clarke M, Collins R, Darby S et al. Effects of radiotherapy and of differences in the extent of surgery for early breast cancer on local recurrence and 15-year survival: an overview of the randomised trials. Lancet 2005; 366: 2087-2106

52 Clavarezza M, Del Mastro L, Venturini M. Taxane-containing chemotherapy in the treatment of early breast cancer patients. Ann Oncol 2006; 17 (Suppl. 7): vii22-vii26

53 Clohisy DR. Metastatic bone disease: future directions. Clin Orthop Relat Res 2003; 1 (415 Suppl.): 1-5

54 Carrick S, Parker S, Thornton CE et al. Single agent versus combination chemotherapy for metastatic breast cancer. Cochrane Database Syst Rev 2009; (2): CD003372

55 Carrick S, Parker S, Wilcken $N$ et al. Single agent versus combination chemotherapy for metastatic breast cancer. Cochrane Database Syst Rev 2005; (2): CD003372

56 Cramp F, Daniel J. Exercise for the management of cancer-related fatigue in adults. Cochrane Database Syst Rev 2008; (2): CD006145

57 Edwards AG, Hailey S, Maxwell M. Psychological interventions for women with metastatic breast cancer. Cochrane Database Syst Rev 2004; (2): CD004253

58 Farquhar C, Marjoribanks J, Basser R et al. High dose chemotherapy and autologous bone marrow or stem cell transplantation versus conventional chemotherapy for women with metastatic breast cancer. Cochrane Database Syst Rev 2005; (3): CD003142

59 Ferguson T, Wilcken N, Vagg R et al. Taxanes for adjuvant treatment of early breast cancer. Cochrane Database Syst Rev 2007; (4): CD004421 
60 Gibson L, Lawrence D, Dawson C et al. Aromatase inhibitors for treatment of advanced breast cancer in postmenopausal women. Cochrane Database Syst Rev 2009; (4): CD003370

61 Goodwin A, Parker S, Ghersi D et al. Post-operative radiotherapy for ductal carcinoma in situ of the breast. Cochrane Database Syst Rev 2009; (4): CD000563

62 Hart MG, Grant $R$, Walker $M$ et al. Surgical resection and whole brain radiation therapy versus whole brain radiation therapy alone for single brain metastases. Cochrane Database of Systematic Review 2004; (4): CD003292

63 Hickey BE, Francis D, Lehman MH. Sequencing of chemotherapy and radiation therapy for early breast cancer. Cochrane Database Syst Rev 2006; (4): CD005212

64 Horneber MA, Bueschel G, Huber R et al. Rostock M. Mistletoe therapy in oncology. Cochrane Database Syst Rev 2008; (2): CD003297

65 Lostumbo L, Carbine NE, Wallace J. Prophylactic mastectomy for the prevention of breast cancer. Cochrane Database Syst Rev 2010;: CD002748

66 Markes $M$, Brockow T, Resch KL. Exercise for women receiving adjuvant therapy for breast cancer. Cochrane Database Syst Rev 2006; (4): CD005001

67 McNeely ML, Campbell K, Ospina $M$ et al. Exercise interventions for upper-limb dysfunction due to breast cancer treatment. Cochrane Database Syst Rev 2010; (6): CD005211

68 Rauschecker H, Clarke M, Gatzemeier W et al. Systemic therapy for treating locoregional recurrence in women with breast cancer. Cochrane Database Syst Rev 2001; (4): CD002195

69 Rauschecker HHF, Clarke MJ, Gatzemeier W et al. Systemic therapy for treating locoregional recurrence in women with breast cancer. Cochrane Database Syst Rev 2008; 5: CD002195

70 Rojas MP, Telaro E, Russo A et al. Follow-up strategies for women treated for early breast cancer. Cochrane Database Syst Rev 2000; (4): CD001768

71 Rojas MP, Telaro E, Russo A, Moschetti I, Coe L, Fossati R, Palli D, del Roselli TM, Liberati A. Follow-up strategies for women treated for early breast cancer. Cochrane Database Syst Rev 2005; (1): CD001768

72 Colleoni M, Rotmensz N, Maisonneuve P et al. Prognostic role of the extent of peritumoral vascular invasion in operable breast cancer. Ann Oncol 2007; 18: 1632-1640.

73 Conte PF, Latreille J, Mauriac L et al. Delay in progression of bone metastases in breast cancer patients treated with intravenous pamidronate: results from a multinational randomized controlled trial. The Aredia Multinational Cooperative Group. J Clin Oncol 1996; 14: 2552-2559

74 Crump M. The role of trastuzumab (Herceptin) in the treatment of women with HER2/neu - overexpressing metastatic breast cancer. Toronto (ON): Practice Guideline Report no. 1-15 (Version 2.2004). Cancer Care Ontario; 2005

75 Crump M, Goss PE, Prince $M$ et al. Outcome of extensive evaluation before adjuvant therapy in women with breast cancer and 10 or more positive axillary lymph nodes. J Clin Oncol 1996; 14: 66-69

76 Cutuli B, Cohen-Solal-le Nir C, de Lafontan B et al. Breast-conserving therapy for ductal carcinoma in situ of the breast: the French Cancer Centers' experience. Int J Radiat Oncol Biol Phys 2002; 53: 868-879

77 CuzickJ, Sestak I, Pinder SE et al. Effect of tamoxifen and radiotherapy in women with locally excised ductal carcinoma in situ: long-term results from the UK/ANZ DCIS trial. Lancet Oncol 2011; 12: 21-29

78 Dalberg K, Mattsson A, Sandelin K et al. Outcome of treatment for ipsilateral breast tumor recurrence in early-stage breast cancer. Breast Cancer Res Treat 1998; 49: 69-78

79 Darby S; on Behalf of the Early Breast Cancer Trialists' Collaborative Group, University of Oxford, GB. Overview of the randomised trials of radiotherapy in early breast cancer. SABCS2009; Minisymposium 3, 1. [MS3-1], Slides of the oral presentation at the 32nd Annual SABCS2009: www.sabcs.org/

80 de Azambuja E, Cardoso F, de Castro Jr. G et al. Ki-67 as prognostic marker in early breast cancer: a meta-analysis of published studies involving 12,155 patients. Br J Cancer 2007; 96: 1504-1513

81 de Boer M, van Deurzen CH, van Dijck IA et al. Micrometastases or isolated tumor cells and the outcome of breast cancer. N Engl J Med 2009; 361: 653-663

82 de Boer M, van Dijck JA, Bult P et al. Breast cancer prognosis and occult lymph node metastases, isolated tumor cells, and micrometastases. J Natl Cancer Inst 2010; 102: 410-425

83 Del Turco MR, Ponti A, Bick U et al. Quality indicators in breast cancer care. Eur J Cancer 2010; 46: 2344-2356
84 Deutsch M. Repeat high-dose external beam irradiation for in-breast tumor recurrence after previous lumpectomy and whole breast irradiation. Int J Radiat Oncol Biol Phys 2002; 53: 687-691

85 Devoogdt N, Van Kampen M, Geraerts I et al. Different physical treatment modalities for lymphoedema developing after axillary lymph node dissection for breast cancer: a review. Eur J Obstet Gynecol Reprod Biol 2010; 149: 3-9

86 Domchek SM, Friebel TM, Neuhausen SL et al. Mortality after bilateral salpingo-oophorectomy in BRCA1 and BRCA2 mutation carriers: a prospective cohort study. Lancet Oncol 2006; 7: 223-229

87 Dowsett M, Nielsen TO, A'hern R et al. Assessment of ki67 in breast cancer: recommendations from the international ki67 in breast cancer working group. J Natl Cancer Inst 2011; 103: 1656-1664

88 DRV Bund. Deutsche Rentenversicherung Bund. Reha-Therapiestandards Brustkrebs. Leitlinie für die medizinische Rehabilitation der Rentenversicherung. 2009. deutsche-rentenversicherung.de

89 Dunne C, Burke JP, Morrow M et al. Effect of margin status on local recurrence after breast conservation and radiation therapy for ductal carcinoma in situ. J Clin Oncol 2009; 27: 1615-1620

90 EBCTCG. Effects of radiotherapy and surgery in early breast cancer. An overview of the randomized trials. Early Breast Cancer Trialists' Collaborative Group. N Engl J Med 1995; 333: 1444-1455

91 EBCTCG. Polychemotherapy for early breast cancer: an overview of the randomised trials. Early Breast Cancer Trialists' Collaborative Group. Lancet 1998; 352: 930-942

92 EBCTCG. Effects of chemotherapy and hormonal therapy for early breast cancer on recurrence and 15-year survival: an overview of the randomised trials.Early Breast Cancer Trialists' Collaborative Group. Lancet 2005; 365: 1687-1717

93 EBCTCG. Comparisons between different polychemotherapy regimes for early breast cancer: meta-analysis of long-term outcome among 100000 women in 123 randomised trials. Lancet 2011; Published online December 6, 2011

94 Darby S, McGale P, Correa C et al. Effect of radiotherapy after breastconserving surgery on 10 -year recurrence and 15 -year breast cancer death: meta-analysis of individual patient data for 10,801 women in 17 randomised trials. Lancet 2011; 378: 1707-1716

95 Correa C, McGale P, Taylor C et al. Overview of the randomized trials of radiotherapy in ductal carcinoma in situ of the breast. J Natl Cancer Inst Monogr 2010; 2010: 162-177

96 Davies C, Godwin J, Gray R et al. Relevance of breast cancer hormone receptors and other factors to the efficacy of adjuvant tamoxifen: patient-level meta-analysis of randomised trials. Lancet 2011; 378: 771-784

97 Early Breast Cancer Trialists' Collaborative Group. Multi-agent chemotherapy for early breast cancer. [DKG-R]. Cochrane Database Syst Rev 2003; 3: CD00487

98 EBMG. Evidence-based medicine guidelines 2006. Article ID: evd02580 (025.023). 2006. www.awmf.org

99 EGAPP Working Group. Recommendations from the EGAPP Working Group: can tumor gene expression profiling improve outcomes in patients with breast cancer? Genet Med 2009; 11: 66-73

100 Eiermann W, Pienkowski T, Crown J et al. Phase III study of doxorubicin/cyclophosphamide with concomitant versus sequential docetaxel as adjuvant treatment in patients with human epidermal growth factor receptor 2-normal, node-positive breast cancer: BCIRG-005 trial. J Clin Oncol 2011; 29: 3877-3884

101 Elkin EB, Kim SH, Casper ES et al. Desire for information and involvement in treatment decisions: elderly cancer patients' preferences and their physicians' perceptions. J Clin Oncol 2007; 25: 5275-5280

102 Ellis MJ, Hayes DF, Lippman ME. Treatment of metastatic breast cancer. [AGO]. Cancer 2000; 749-797

103 Elston CW, Ellis IO. Pathological prognostic factors in breast cancer. I. The value of histological grade in breast cancer: experience from a large study with long-term follow-up. Histopathology 1991; 19: 403-410

104 Emdin SO, Granstrand B, Ringberg A et al. SweDCIS: Radiotherapy after sector resection for ductal carcinoma in situ of the breast. Results of a randomised trial in a population offered mammography screening. Acta Oncol 2006; 45: 536-543

105 Estevez LG, Munoz M, Alvarez I et al. Evidence-based use of taxanes in the adjuvant setting of breast cancer. A review of randomized phase III trials. Cancer Treat Rev 2007; 33: 474-483

106 Evans DG, Baildam AD, Anderson E et al. Risk reducing mastectomy: outcomes in 10 European centres. J Med Genet 2009; 46: 254-258 
107 Feher O, Vadvorka P, Jassem J et al. Randomized phase III study of epirubicin (E) versus gemcitabine $(G)$ chemotherapy in elderly females with metastatic breast cancer (MBC). Jk 3 2002; EBCC, Barcelona. [AGO]

108 Fernando SA, Edge SB. Evidence and controversies in the use of postmastectomy radiation. J Natl Compr Canc Netw 2007; 5: 331-338

109 Fisher B, Anderson S. Conservative surgery for the management of invasive and noninvasive carcinoma of the breast: NSABP trials. National Surgical Adjuvant Breast and Bowel Project. World J Surg 1994; 18 : 63-69

110 Fisher B, Anderson S, Wickerham DL et al. Increased intensification and total dose of cyclophosphamide in a doxorubicin-cyclophosphamide regimen for the treatment of primary breast cancer: findings from National Surgical Adjuvant Breast and Bowel Project B-22.J Clin Oncol 1997a; 15: 1858-1869

111 Fisher B, Brown A, Mamounas E et al. Effect of preoperative chemotherapy on local-regional disease in women with operable breast cancer: findings from National Surgical Adjuvant Breast and Bowel Project B-18. J Clin Oncol 1997b; 15: 2483-2493

112 Fisher B, Brown AM, Dimitrov NV et al. Two months of doxorubicin-cyclophosphamide with and without interval reinduction therapy compared with 6 months of cyclophosphamide, methotrexate, and fluorouracil in positive-node breast cancer patients with tamoxifen-nonresponsive tumors: results from the National Surgical Adjuvant Breast and Bowel Project B-15. J Clin Oncol 1990; 8: 1483-1496

113 Fisher B, Dignam J, Wolmark $N$ et al. Tamoxifen and chemotherapy for lymph node-negative, estrogen receptor-positive breast cancer. J Natl Cancer Inst 1997c; 89: 1673-1682

114 Fisher B, Dignam J, Wolmark $N$ et al. Tamoxifen in treatment of intraductal breast cancer: National Surgical Adjuvant Breast and Bowel Project B-24 randomised controlled trial. Lancet 1999; 353: 1993 2000

115 Fisher B, Land S, Mamounas E et al. Prevention of invasive breast cancer in women with ductal carcinoma in situ: an update of the national surgical adjuvant breast and bowel project experience. Semin Oncol 2001; 28: 400-418

116 Fleissig A, Fallowfield LJ, Langridge CI et al. Post-operative arm morbidity and quality of life. Results of the ALMANAC randomised trial comparing sentinel node biopsy with standard axillary treatment in the management of patients with early breast cancer. Breast Cancer Res Treat 2006; 95: 279-293

117 Floyd SR, Taghian AG. Post-mastectomy radiation in large node-negative breast tumors: does size really matter? Radiother Oncol 2009; 91: 33-37

118 Ford S, Schofield T, Hope T. Observing decision-making in the general practice consultation: who makes which decisions? Health Expect 2006; 9: 130-137

119 Fossati $R$, Confalonieri $C$, Torri $V$ et al. Cytotoxic and hormonal treatment for metastatic breast cancer: a systematic review of published randomized trials involving 31,510 women. J Clin Oncol 1998; 16: 3439-3460

120 Fourney DR, Gokaslan ZL. Thoracolumbar spine: surgical treatment of metastatic disease. [DKG-R]. Current Opinion in Orthopedics 2003; 14: $144-152$

121 Francis P, Crown J, Di Leo A et al. Adjuvant chemotherapy with sequential or concurrent anthracycline and docetaxel: Breast International Group 02-98 randomized trial. J Natl Cancer Inst 2008; 100: 121-133

122 Francis WP, Abghari P, Du W et al. Improving surgical outcomes: standardizing the reporting of incidence and severity of acute lymphedema after sentinel lymph node biopsy and axillary lymph node dissection. Am J Surg 2006; 192: 636-639

123 French Adjuvant Study Group. Benefit of a high-dose epirubicin regimen in adjuvant chemotherapy for node-positive breast cancer patients with poor prognostic factors: 5-year follow-up results of French Adjuvant Study Group 05 Randomized Trial. [CANADA]. J Clin Oncol 2001; 19: 602-611

124 Fumoleau P, Kerbrat P, Romestaing P et al. Randomized trial comparing six versus three cycles of epirubicin-based adjuvant chemotherapy in premenopausal, node-positive breast cancer patients: 10-year follow-up results of the French Adjuvant Study Group 01 trial. J Clin Oncol 2003; 21: 298-305

125 Garg AK, Oh JL, Oswald MJ et al. Effect of postmastectomy radiotherapy in patients $<35$ years old with stage II-III breast cancer treated with doxorubicin-based neoadjuvant chemotherapy and mastectomy. Int J Radiat Oncol Biol Phys 2007; 69: 1478-1483
126 Gasparini G, Weidner N, Bevilacqua P et al. Tumor microvessel density, p53 expression, tumor size, and peritumoral lymphatic vessel invasion are relevant prognostic markers in node-negative breast carcinoma. J Clin Oncol 1994; 12: 454-466

127 Gebski V, Lagleva M, Keech A et al. Survival effects of postmastectomy adjuvant radiation therapy using biologically equivalent doses: a clinical perspective. J Natl Cancer Inst 2006; 98: 26-38

128 Geller BM, Kerlikowske K, Carney PA et al. Mammography surveillance following breast cancer. Breast Cancer Res Treat 2003; 81: 107-115

129 GIVIO Investigators. Impact of follow-up testing on survival and health-related quality of life in breast cancer patients. A multicenter randomized controlled trial. The GIVIO Investigators. JAMA 1994; 271: 1587-1592

130 Goldhirsch A, Ingle JN, Gelber RD et al. Thresholds for therapies: highlights of the St Gallen International Expert Consensus on the primary therapy of early breast cancer 2009. Ann Oncol 2009; 20: 1319-1329

131 Goldhirsch A, Wood WC, Coates AS et al. Strategies for subtypes - dealing with the diversity of breast cancer: highlights of the St. Gallen International Expert Consensus on the Primary Therapy of Early Breast Cancer 2011. Ann Oncol 2011; 22: 1736-1747

132 Golshan M, Martin WJ, Dowlatshahi K. Sentinel lymph node biopsy lowers the rate of lymphedema when compared with standard axillary lymph node dissection. Am Surg 2003; 69: 209-211

133 Gruber R, Bernt R, Helbich TH. [Cost-effectiveness of percutaneous core needle breast biopsy (CNBB) versus open surgical biopsy (OSB) of nonpalpable breast lesions: metaanalysis and cost evaluation for German-speaking countries]. Rofo 2008; 180: 134-142

134 Grunfeld E, Dhesy-Thind S, Levine M. Clinical practice guidelines for the care and treatment of breast cancer: follow-up after treatment for breast cancer (summary of the 2005 update). CMAJ 2005; 172: $1319-1320$

135 Grunfeld E, Noorani H, McGahan L et al. Surveillance mammography after treatment of primary breast cancer: a systematic review. Breast 2002; 11: 228-235

136 Gulliford T, Opomu M, Wilson E et al. Popularity of less frequent follow up for breast cancer in randomised study: initial findings from the hotline study. BMJ 1997; 314: 174-177

137 Haffty BG, Reiss M, Beinfield $M$ et al. Ipsilateral breast tumor recurrence as a predictor of distant disease: implications for systemic therapy at the time of local relapse. J Clin Oncol 1996; 14: 52-57

138 Harbeck N, Schmitt M, Meisner C et al. Final 10-year analysis of prospective multicenter Chemo NO trial for validation of ASCO-recommended biomarkers uPA/PAI-1 for therapy decision making in nodenegative breast cancer. J Clin Oncol 2009; 27 (15 Suppl.): Abstr. 511

139 Halyard MY, Pisansky TM, Dueck AC et al. Radiotherapy and adjuvant trastuzumab in operable breast cancer: tolerability and adverse event data from the NCCTG Phase III Trial N9831. J Clin Oncol 2009; 27: 2638-2644

140 Hammond ME, Hayes DF, Dowsett M et al. American Society of Clinical Oncology/College Of American Pathologists guideline recommendations for immunohistochemical testing of estrogen and progesterone receptors in breast cancer. J Clin Oncol 2010; 28: 2784-2795

141 Hamner JB, Fleming MD. Lymphedema therapy reduces the volume of edema and pain in patients with breast cancer. Ann Surg Oncol 2007; 14: 1904-1908

142 Harnett $A$. Fewer fractions of adjuvant external beam radiotherapy for early breast cancer are safe and effective and can now be the standard of care. Why the UK's NICE accepts fewer fractions as the standard of care for adjuvant radiotherapy in early breast cancer. Breast 2010; 19: 159-162

143 Harnett A, Smallwood J, Titshall $V$ et al. Diagnosis and treatment of early breast cancer, including locally advanced disease - summary of NICE guidance. BMJ 2009; 338: b438

144 Harris EE. Cardiac mortality and morbidity after breast cancer treatment. Cancer Control 2008; 15: 120-129

145 Harris EE, Christensen VJ, Hwang WT et al. Impact of concurrent versus sequential tamoxifen with radiation therapy in early-stage breast cancer patients undergoing breast conservation treatment. J Clin Oncol 2005; 23: 11-16

146 Harris L, Fritsche H, Mennel R et al. American Society of Clinical Oncology 2007 update of recommendations for the use of tumor markers in breast cancer. J Clin Oncol 2007; 25: 5287-5312

147 Harris SR, Hugi MR, Olivotto IA et al. Clinical practice guidelines for the care and treatment of breast cancer: 11. Lymphedema. CMAJ 2001; 164: 191-199 
148 Hauner D, Janni W, Rack B et al. The effect of overweight and nutrition on prognosis in breast cancer. Dtsch Arztebl Int 2011; 108: 795-801

149 Hayes DF. Clinical practice. Follow-up of patients with early breast cancer. N Engl J Med 2007; 356: 2505-2513

150 Hayes DF, Henderson IC, Shapiro CL. Treatment of metastatic breast cancer: present and future prospects. Semin Oncol 1995; 22 (2 Suppl. 5): 5-19

151 Hayes S, Cornish B, Newman B. Comparison of methods to diagnose lymphoedema among breast cancer survivors: 6-month follow-up. Breast Cancer Res Treat 2005; 89: 221-226

152 Henderson IC, Berry DA, Demetri GD et al. Improved outcomes from adding sequential Paclitaxel but not from escalating Doxorubicin dose in an adjuvant chemotherapy regimen for patients with nodepositive primary breast cancer. J Clin Oncol 2003; 21: 976-983

153 Hoeller U, Borgmann K, Feyer P et al. [On the interaction of adjuvant radiotherapy and tamoxifen treatment for breast cancer]. Strahlenther Onkol 2007; 183: 535-544

154 Holmberg L, Garmo H, Granstrand B et al. Absolute risk reductions for local recurrence after postoperative radiotherapy after sector resection for ductal carcinoma in situ of the breast. J Clin Oncol 2008; 26: 1247-1252

155 Honrado E, Osorio A, Palacios J et al. Pathology and gene expression of hereditary breast tumors associated with BRCA1, BRCA2 and CHEK2 gene mutations. Oncogene 2006; 25: 5837-5845

156 Hortobagyi GN, Piccart-Gebhart MJ. Current management of advanced breast cancer. Semin Oncol 1996; 23 (5 Suppl. 11): 1-5

157 Hortobagyi GN, Theriault RL, Lipton A et al. Long-term prevention of skeletal complications of metastatic breast cancer with pamidronate. Protocol 19 Aredia Breast Cancer Study Group. J Clin Oncol 1998; 16: 2038-2044

158 Hoskin PJ, Yarnold JR, Roos DR et al. Second workshop on palliative radiotherapy and symptom control: radiotherapy for bone metastases. [DKG-N]. Clin Oncol (R Coll Radiol). Clin Oncol 2001; 13: 88-90

159 Houghton J, George WD, Cuzick J et al. Radiotherapy and tamoxifen in women with completely excised ductal carcinoma in situ of the breast in the UK, Australia, and New Zealand: randomised controlled trial. Lancet 2003: 362: 95-102

160 Houssami N, Ciatto S, Macaskill P et al. Accuracy and surgical impact of magnetic resonance imaging in breast cancer staging: systematic review and meta-analysis in detection of multifocal and multicentric cancer. J Clin Oncol 2008; 26: 3248-3258

161 Houssami $N$, Hayes DF. Review of preoperative magnetic resonance imaging (MRI) in breast cancer: should MRI be performed on all women with newly diagnosed, early stage breast cancer? CA Cancer J Clin 2009; 59: 290-302

162 Houssami N, Macaskill P, Marinovich ML et al. Meta-analysis of the impact of surgical margins on local recurrence in women with earlystage invasive breast cancer treated with breast-conserving therapy. Eur J Cancer 2010; 46: 3219-3232

163 Huang EH, Strom EA, Perkins GH et al. Comparison of risk of local-regional recurrence after mastectomy or breast conservation therapy for patients treated with neoadjuvant chemotherapy and radiation stratified according to a prognostic index score. Int J Radiat Oncol Biol Phys 2006; 66: 352-357

164 Hurria A, Hudis C. Follow-up care of breast cancer survivors. Crit Rev Oncol Hematol 2003; 48: 89-99

165 ICSI. Health care guideline: breast cancer treatment. 2005. www. guideline.gov

166 Jagsi R, Pierce L. Postmastectomy radiation therapy for patients with locally advanced breast cancer. Semin Radiat Oncol 2009; 19: 236243

167 Janicke F, Prechtl A, Thomssen C et al.; German N0 Study Group. Randomized adjuvant therapy trial in high-risk lymph node-negative breast cancer patients identified by urokinase-type plasminogen activator and plasminogen activator inhibitor type I. J Natl Cancer Inst 2001; 93: 913-920

168 Johnson RC, Banerjee D, Webster DJ. Mastectomy follow-up by biennial mammograms: is it worthwhile? Breast 2000; 9: 93-95

169 Jones HA, Antonini N, Hart AA et al. Impact of pathological characteristics on local relapse after breast-conserving therapy: a subgroup analysis of the EORTC boost versus no boost trial. J Clin Oncol 2009; 27: 4939-4947

170 Jones EL, Oleson JR, Prosnitz LR et al. Randomized trial of hyperthermia and radiation for superficial tumors. J Clin Oncol 2005; 23: 30793085
171 Jubelirer SJ. Surveillance testing in patients with early stage breast cancer: a review. W V Med J 1998; 94: 14-17

172 Karasawa K, Katsui K, Seki K et al. Radiotherapy with concurrent docetaxel for advanced and recurrent breast cancer. Breast Cancer 2003; 10: $268-274$

173 Kato T, Kameoka S, Kimura $T$ et al. The combination of angiogenesis and blood vessel invasion as a prognostic indicator in primary breast cancer. Br J Cancer 2003; 88: 1900-1908

174 Kaufmann M, Hortobagyi GN, Goldhirsch A et al. Recommendations from an international expert panel on the use of neoadjuvant (primary) systemic treatment of operable breast cancer: an update. J Clin Oncol 2006; 24: 1940-1949

175 Kaufmann M, Morrow M, von Minckwitz G et al. Locoregional treatment of primary breast cancer: consensus recommendations from an International Expert Panel. Cancer 2010; 116: 1184-1191

176 Kaufmann M, von Minckwitz G, Smith $R$ et al. International expert panel on the use of primary (preoperative) systemic treatment of operable breast cancer: review and recommendations. J Clin Oncol 2003; 21: 2600-2608

177 Kelly CM, Wilkins RM, Eckardt JJ et al. Treatment of metastatic disease of the tibia. Clin Orthop Relat Res 2003; 1 (415 Suppl.): S219-S229

178 Khatcheressian JL, Wolff AC, Smith TJ et al. American Society of Clinical Oncology 2006 update of the breast cancer follow-up and management guidelines in the adjuvant setting. J Clin Oncol 2006; 24: 5091-5097

179 Kirova YM, Caussa L, Granger B et al. [Monocentric evaluation of the skin and cardiac toxicities of the concomitant administration of trastuzumab and radiotherapy]. Cancer Radiother 2009; 13: 276-280

180 Klemperer D, Lang B, Koch $K$ et al. Gute Praxis Gesundheitsinformation. Z Evid Fortbild Qual Gesundh wesen (ZEFQ) 2010; 104: 66-68

181 Klijn JG, Blamey RW, Boccardo F et al. Combined tamoxifen and luteinizing hormone-releasing hormone (LHRH) agonist versus LHRH agonist alone in premenopausal advanced breast cancer: a meta-analysis of four randomized trials. J Clin Oncol 2001; 19: 343-353

182 Koizumi M, Yoshimoto M, Kasumi F et al. Comparison between solitary and multiple skeletal metastatic lesions of breast cancer patients. Ann Oncol 2003; 14: 1234-1240

183 Kollias J, Evans AJ, Wilson AR et al. Value of contralateral surveillance mammography for primary breast cancer follow-up. World J Surg 2000; 24: 983-987

184 Kondziolka D, Patel A, Lunsford LD et al. Stereotactic radiosurgery plus whole brain radiotherapy versus radiotherapy alone for patients with multiple brain metastases. [DKG-N]. Int J Radiat Oncol Biol Phys 1999; 45: 427-434

185 Krag DN, Anderson SJ, Julian TB et al. Sentinel-lymph-node resection compared with conventional axillary-lymph-node dissection in clinically node-negative patients with breast cancer: overall survival findings from the NSABP B-32 randomised phase 3 trial. Lancet Oncol 2010; 11: 927-933

186 Kuehn T, Bembenek A, Decker T et al. A concept for the clinical implementation of sentinel lymph node biopsy in patients with breast carcinoma with special regard to quality assurance. Cancer 2005; 103 : 451-461

187 Kunkler I. Adjuvant chest wall radiotherapy for breast cancer: black, white and shades of grey. Eur J Surg Oncol 2010; 36: 331-334

188 Kurtz JM, Amalric R, Brandone $\mathrm{H}$ et al. Local recurrence after breastconserving surgery and radiotherapy. Frequency, time course, and prognosis. Cancer 1989; 63: 1912-1917

189 Kurtz JM, Jacquemier J, Amalric R et al. Is breast conservation after local recurrence feasible? Eur J Cancer 1991; 27: 240-244

190 Kyndi M, Sorensen FB, Knudsen $H$ et al. Impact of BCL2 and p53 on postmastectomy radiotherapy response in high-risk breast cancer. A subgroup analysis of DBCG82 b\&c. Acta Oncol 2008a; 47: 608-617

191 Kyndi M, Sorensen FB, Knudsen $H$ et al. Estrogen receptor, progesterone receptor, HER-2, and response to postmastectomy radiotherapy in high-risk breast cancer: the Danish Breast Cancer Cooperative Group. J Clin Oncol 2008b; 26: 1419-1426

192 Lakhani SR, Jacquemier J. Sloane JP et al. Multifactorial analysis of differences between sporadic breast cancers and cancers involving BRCA1 and BRCA2 mutations. J Natl Cancer Inst 1998; 90: 1138-1145

193 Lakhani SR, Reis-Filho JS, Fulford L et al. Prediction of BRCA1 status in patients with breast cancer using estrogen receptor and basal phenotype. Clin Cancer Res 2005; 11: 5175-5180 
194 Lanitis S, Tekkis PP, Sgourakis G et al. Comparison of skin-sparing mastectomy versus non-skin-sparing mastectomy for breast cancer: a meta-analysis of observational studies. Ann Surg 2010; 251: 632-639

195 Lemieux J, Goodwin PJ, Bordeleau LJ et al. Quality-of-life measurement in randomized clinical trials in breast cancer: an updated systematic review (2001-2009). J Natl Cancer Inst 2011; 103: 178-231

196 Livi L, Borghesi S, Saieva C et al. Benefit of radiation boost after wholebreast radiotherapy. Int J Radiat Oncol Biol Phys 2009; 75: 1029-1034

197 Look MP, van Putten WL, Duffy MJ et al. Pooled analysis of prognostic impact of urokinase-type plasminogen activator and its inhibitor PAI-1 in 8377 breast cancer patients. J Natl Cancer Inst 2002; 94: 116-128

198 Loprinzi CL. Follow-up care after breast cancer treatment. Mayo Clin Womens Healthsource 2004; 8: Suppl. 1-2

199 Lupe K, Truong PT, Alexander C et al. Ten-year locoregional recurrence risks in women with nodal micrometastatic breast cancer staged with axillary dissection. Int J Radiat Oncol Biol Phys 2011; 81: e681-e688

200 Lyman GH, Giuliano AE, Somerfield MR et al. American Society of Clinical Oncology guideline recommendations for sentinel lymph node biopsy in early-stage breast cancer. J Clin Oncol 2005; 23: 7703-7720

$201 \mathrm{Madjar} \mathrm{H}$. Role of breast ultrasound for the detection and differentiation of breast lesions. Breast Care (Basel) 2010; 5: 109-114

202 Madjar H, Mundinger A, Degenhardt F et al. Qualitätskontrolle in der Mamma-Sonographie. Ultraschall in Med 2003; 24: 190-194

203 Madjar H, Ohlinger R, Mundinger A et al. BI-RADS-analogue DEGUM criteria for findings in breast ultrasound - consensus of the DEGUM Committee on Breast Ultrasound. Ultraschall Med 2006; 27: 374-379

204 Mamounas EP, Bryant J, Lembersky B et al. Paclitaxel after doxorubicin plus cyclophosphamide as adjuvant chemotherapy for node-positive breast cancer: results from NSABP B-28. J Clin Oncol 2005; 23: 36863696

205 Mansel RE, Fallowfield L, Kissin $M$ et al. Randomized multicenter trial of sentinel node biopsy versus standard axillary treatment in operable breast cancer: the ALMANAC Trial. J Natl Cancer Inst 2006; 98 : 599-609

206 Marchionni L, Wilson RF, Wolff AC et al. Systematic review: gene expression profiling assays in early-stage breast cancer. Ann Intern Med 2008; 148: 358-369

207 McCammon R, Finlayson C, Schwer A et al. Impact of postmastectomy radiotherapy in T3N0 invasive carcinoma of the breast: a Surveillance, Epidemiology, and End Results database analysis. Cancer 2008; 113: 683-689

208 McGuire SE, Gonzalez-Angulo AM, Huang EH et al. Postmastectomy radiation improves the outcome of patients with locally advanced breast cancer who achieve a pathologic complete response to neoadjuvant chemotherapy. Int J Radiat Oncol Biol Phys 2007; 68: 10041009

209 Moebus V, Jackisch C, Lueck HJ et al. Intense dose-dense sequential chemotherapy with epirubicin, paclitaxel, and cyclophosphamide compared with conventionally scheduled chemotherapy in high-risk primary breast cancer: mature results of an AGO phase III study. J Clin Oncol 2010; 28: 2874-2880

210 Moseley AL, Carati CJ, Piller NB. A systematic review of common conservative therapies for arm lymphoedema secondary to breast cancer treatment. Ann Oncol 2007; 18: 639-646

211 Mouridsen H, Sun Y, Gershanovich M et al. First-line therapy with letrozole (Femara) for advanced breast cancer prolongs time to worsening of Karnofsky Performance Status compared with tamoxifen. Breast Canc Res Treat 2001a; 69: abstract

212 Mouridsen H, Gershanovich M, Sun Y et al. Superior efficacy of letrozole versus tamoxifen as first-line therapy for postmenopausal women with advanced breast cancer: results of a phase III study of the International Letrozole Breast Cancer Group. J Clin Oncol 2001b; 19: 2596-2606

213 NBOCC; National Breast and Ovarian Cancer Center. Recommendations for use of Chemotherapy for the treatment of advanced breast cancer. Surry Hills: NBOCC; 2010a

214 NBOCC; National Breast and Ovarian Cancer Centre. Recommendations for follow-up of women with early breast cancer. Surry Hills: NBOCC; 2010b

215 NCCN. Practice guidelines in oncology - Version 2. Fort Washington, PA (USA): NCCN; 2006

216 NCCN. Clinical practice guidelines in oncology: breast cancer - Version V.1. Fort Washington, PA (USA): NCCN; 2007
217 NCCN; National Comprehensive Cancer Network. Breast cancer V. 2.2011. Fort Washington, PA (USA): NCCN; 2011

218 NCRI. UK clinical guidelines for the use of adjuvant trastuzumab (Herceptin $^{\circledR}$ ) with or following chemotherapy in HER2-positive early breast cancer. London (UK): NCRI; 2005

219 NHMRC. Clinical practice guidelines for the management of early breast cancer. Canberra (Australien): NHMRC; 2001

220 National Institute for Clinical Excellence (NICE). Advanced breast cancer: diagnosis and treatment. London (UK): NICE; 2009a

221 National Institute for Clinical Excellence (NICE). Early and locally advanced breast cancer: diagnosis and treatment. London (UK): NICE; $2009 \mathrm{~b}$

222 Nielsen HM, Overgaard M, Grau C et al. Loco-regional recurrence after mastectomy in high-risk breast cancer - risk and prognosis. An analysis of patients from the DBCG $82 \mathrm{~b} \& \mathrm{c}$ randomization trials. Radiother Oncol 2006a; 79: 147-155

223 Nielsen HM, Overgaard M, Grau C et al. Study of failure pattern among high-risk breast cancer patients with or without postmastectomy radiotherapy in addition to adjuvant systemic therapy: long-term results from the Danish Breast Cancer Cooperative Group DBCG 82 b and c randomized studies. J Clin Oncol 2006b; 24: 2268-2275

224 NIH; National Institutes of Health Consensus Development Panel. National Institutes of Health Consensus Development Conference statement: adjuvant therapy for breast cancer November 1-3, 2000. [CANADA]. Bethesda 2001. Bethesda (MD): NIH. http://odp.od.nih.gov/ consensus/cons/114/114_statement.htm; last access: 2001

225 Nothacker M, Duda V, Hahn M et al. Early detection of breast cancer: benefits and risks of supplemental breast ultrasound in asymptomatic women with mammographically dense breast tissue. A systematic review. BMC Cancer 2009; 9: 335

226 Nothacker M, Lelgemann M, Giersiepen K et al. Evidenzbericht 2007 zur S3-Leitlinie Brustkrebsfrüherkennung in Deutschland. Berlin: Ärztliches Zentrum für Qualität in der Medizin; 2007

227 NZGG; New Zealand Guidelines Group. Management of early breast cancer. Wellington: NZGG; 2009

228 O'Higgins N, Linos DA, Blichert-Toft $M$ et al. European guidelines for quality assurance in the surgical management of mammographically detected lesions. Eur J Surg Oncol 1998; 24: 96-98

229 O'Rourke N, McCloskey E, Houghton F et al. Double-blind, placebo-controlled, dose-response trial of oral clodronate in patients with bone metastases. J Clin Oncol 1995; 13: 929-934

230 Omlin A, Amichetti M, Azria D et al. Boost radiotherapy in young women with ductal carcinoma in situ: a multicentre, retrospective study of the Rare Cancer Network. Lancet Oncol 2006; 7: 652-656

231 Osborne CK. Steroid hormone receptors in breast cancer management. Breast Cancer Res Treat 1998; 51: 227-238

232 Overgaard $M$, Nielsen HM, Overgaard $J$. Is the benefit of postmastectomy irradiation limited to patients with four or more positive nodes, as recommended in international consensus reports? A subgroup analysis of the DBCG $82 \mathrm{~b} \& \mathrm{c}$ randomized trials. Radiother Oncol 2007; 82: 247-253

233 Page DL, Jensen RA, Simpson JF. Routinely available indicators of prognosis in breast cancer. Breast Cancer Res Treat 1998; 51: 195-208

234 Page DL, Rogers LW. Combined histologic and cytologic criteria for the diagnosis of mammary atypical ductal hyperplasia. Hum Pathol 1992; 23: $1095-1097$

235 Paik S, Shak S, Tang G et al. A multigene assay to predict recurrence of tamoxifen-treated, node-negative breast cancer. N Engl J Med 2004; 351: 2817-2826

236 Paik S, Tang G, Shak S et al. Gene expression and benefit of chemotherapy in women with node-negative, estrogen receptor-positive breast cancer. J Clin Oncol 2006; 24: 3726-3734

237 Palli D, Russo A, Saieva $C$ et al. Intensive vs. clinical follow-up after treatment of primary breast cancer: 10 -year update of a randomized trial. National Research Council Project on Breast Cancer Follow-up. JAMA 1999; 281: 1586

238 Park CC, Mitsumori M, Nixon A et al. Outcome at 8 years after breastconserving surgery and radiation therapy for invasive breast cancer: influence of margin status and systemic therapy on local recurrence. J Clin Oncol 2000; 18: 1668-1675

239 Pestalozzi BC, Luporsi-Gely E, Jost LM et al. ESMO Minimum Clinical Recommendations for diagnosis, adjuvant treatment and follow-up of primary breast cancer. Ann Oncol 2005; 16 (Suppl. 1): i7-i9 
240 Peto $R$. Highlights from the 2005/6 EBCTCG worldwide overview of every women in all the trials in early breast cancer. 29th Annual San Antonio Breast Cancer Symposium 2006; Abstract book \# 40

241 Petrelli F, Barni S. Meta-analysis of concomitant compared to sequential adjuvant trastuzumab in breast cancer: the sooner the better. Med Oncol 2012; 29: 503-510

242 Pierce LJ, Hutchins LF, Green SR et al. Sequencing of tamoxifen and radiotherapy after breast-conserving surgery in early-stage breast cancer. J Clin Oncol 2005; 23: 24-29

243 Politi MC, Han PK, Col NF. Communicating the uncertainty of harms and benefits of medical interventions. Med Decis Making 2007; 27: 681-695

244 Poortmans P. Evidence based radiation oncology: breast cancer. Radiother Oncol 2007; 84: 84-101

245 Poortmans PM, Collette L, Bartelink $H$ et al. The addition of a boost dose on the primary tumour bed after lumpectomy in breast conserving treatment for breast cancer. A summary of the results of EORTC22881-10882 "boost versus no boost" trial. Cancer Radiother 2008; 12: 565-570

246 Poortmans PM, Collette L, Horiot JC et al. Impact of the boost dose of $10 \mathrm{~Gy}$ versus $26 \mathrm{~Gy}$ in patients with early stage breast cancer after a microscopically incomplete lumpectomy: 10-year results of the randomised EORTC boost trial. Radiother Oncol 2009; 90: 80-85

247 Potter S, Brigic A, Whiting PF et al. Reporting clinical outcomes of breast reconstruction: a systematic review. J Natl Cancer Inst 2011; 103: $31-46$

248 Recht $A$. Integration of systemic therapy and radiation therapy for patients with early-stage breast cancer treated with conservative surgery. Clin Breast Cancer 2003; 4: 104-113

249 Recht A. Radiotherapy, antihormonal therapy, and personalised medicine. Lancet Oncol 2010; 11: 215-216

250 Renton SC, Gazet JC, Ford HT et al. The importance of the resection margin in conservative surgery for breast cancer. Eur J Surg Oncol 1996; 22: 17-22

251 Robert NJ, Dieras V, Glaspy J et al. RIBBON-1: randomized, doubleblind, placebo-controlled, phase III trial of chemotherapy with or without bevacizumab for first-line treatment of human epidermal growth factor receptor 2-negative, locally recurrent or metastatic breast cancer. J Clin Oncol 2011; 29: 1252-1260

252 Robertson JF, Osborne CK, Howell A et al. Fulvestrant versus anastrozole for the treatment of advanced breast carcinoma in postmenopausal women: a prospective combined analysis of two multicenter trials. Cancer 2003; 98: 229-238

253 Roche H, Fumoleau P, Spielmann M et al. Sequential adjuvant epirubicin-based and docetaxel chemotherapy for node-positive breast cancer patients: the FNCLCC PACS01 Trial. J Clin Oncol 2006; 24: 56645671

254 Romestaing P, Belot A, Hennequin C. Ten-year results of a randomized trial of internal mammary chain irradiation after mastectomy. Int J Radiat Oncol Biol Phys 2009; 75 (Suppl. 3): p S1 [Abstract 1]

255 Romestaing $P$, Lehingue $Y$, Carrie C et al. Role of a 10-Gy boost in the conservative treatment of early breast cancer: results of a randomized clinical trial in Lyon, France. J Clin Oncol 1997; 15: 963-968

256 Romond EH, Perez EA, Bryant J et al. Trastuzumab plus adjuvant chemotherapy for operable HER2-positive breast cancer. $N$ Engl J Med 2005; 353: 1673-1684

257 Roos DE, O'Brien PC, Smith JG et al. A role for radiotherapy in neuropathic bone pain: preliminary response rates from a prospective trial (Trans-tasman radiation oncology group, TROG 96.05). Int J Radiat Oncol Biol Phys 2000; 46: 975-981

258 Rosen LS, Gordon D, Kaminski M et al. Zoledronic acid versus pamidronate in the treatment of skeletal metastases in patients with breast cancer or osteolytic lesions of multiple myeloma: a phase III, doubleblind, comparative trial. Cancer J 2001; 7: 377-387

259 Rosen PP, Groshen S, Kinne DW. Prognosis in T2N0M0 stage I breast carcinoma: a 20-year follow-up study. J Clin Oncol 1991; 9: 16501661

260 Rosen PP, Groshen S, Kinne DW et al. Factors influencing prognosis in node-negative breast carcinoma: analysis of 767 T1NOM0/T2NOM0 patients with long-term follow-up. J Clin Oncol 1993; 11: 2090-2100

261 Rosselli Del T, Palli D, Cariddi A et al. Intensive diagnostic follow-up after treatment of primary breast cancer. A randomized trial. National Research Council Project on Breast Cancer follow-up. JAMA 1994; 271: 1593-1597
262 Rouesse J, de la Lande B, Bertheault-Cvitkovic F et al. A phase III randomized trial comparing adjuvant concomitant chemoradiotherapy versus standard adjuvant chemotherapy followed by radiotherapy in operable node-positive breast cancer: final results. Int J Radiat Oncol Biol Phys 2006; 64: 1072-1080

263 Rowell NP. Radiotherapy to the chest wall following mastectomy for node-negative breast cancer: a systematic review. Radiother Oncol 2009; 91: 23-32

264 Rowell NP. Are mastectomy resection margins of clinical relevance? A systematic review. Breast 2010; 19: 14-22

265 Russell NS, Kunkler IH, van Tienhoven G et al. Postmastectomy radiotherapy: will the selective use of postmastectomy radiotherapy study end the debate? J Clin Oncol 2009; 27: 996-997

266 S3 Leitlinie Magenkarzinom. Diagnostik und Therapie der Adenokarzinome des Magens und ösophagogastralen Übergangs. AWMF; 2011

267 Sanjuan A, Vidal-Sicart S, Zanon G et al. Clinical axillary recurrence after sentinel node biopsy in breast cancer: a follow-up study of 220 patients. Eur J Nucl Med Mol Imaging 2005; 32: 932-936

268 Sautter-Bihl ML, Budach W, Dunst J et al. DEGRO practical guidelines for radiotherapy of breast cancer I: breast-conserving therapy. Strahlenther Onkol 2007; 183: 661-666

269 Schmoor C, Sauerbrei W, Bastert G et al. Role of isolated locoregional recurrence of breast cancer: results of four prospective studies. J Clin Oncol 2000; 18: 1696-1708

270 Seidman $A D$, Fornier $M N$, Esteva FJ et al. Weekly trastuzumab and paclitaxel therapy for metastatic breast cancer with analysis of efficacy by HER2 immunophenotype and gene amplification. J Clin Oncol 2001; 19: 2587-2595

271 Selby P, Gillis C, Haward R. Benefits from specialised cancer care. Lancet 1996; 348: 313-318

272 Semrau S, Gerber B, Reimer T et al. Concurrent radiotherapy and taxane chemotherapy in patients with locoregional recurrence of breast cancer. A retrospective analysis. Strahlenther Onkol 2006; 182: 596603

273 Shaffer R, Tyldesley S, Rolles $M$ et al. Acute cardiotoxicity with concurrent trastuzumab and radiotherapy including internal mammary chain nodes: a retrospective single-institution study. Radiother Oncol 2009; 90: 122-126

274 Shafiq J, Delaney G, Barton MB. An evidence-based estimation of local control and survival benefit of radiotherapy for breast cancer. Radiother Oncol 2007; 84: 11-17

275 Sheard T, Maguire $P$. The effect of psychological interventions on anxiety and depression in cancer patients: results of two meta-analyses. Br J Cancer 1999; 80: 1770-1780

276 Shelley W, McCready D, Holloway C et al.; and the Breast Cancer Disease Site Group. Management of ductal carcinoma in situ of the breast: a clinical practice guideline. Evidence-based Series \#1-10 Version 2.2006: Section 1. Hamilton, ON: Cancer Care Ontario; 2006

277 Shenkier T, Weir L, Levine $M$ et al. Clinical practice guidelines for the care and treatment of breast cancer: 15 . Treatment for women with stage III or locally advanced breast cancer. CMAJ 2004; 170: 983-994

278 Sherar M, Liu FF, Pintilie $M$ et al. Relationship between thermal dose and outcome in thermoradiotherapy treatments for superficial recurrences of breast cancer: data from a phase III trial. Int J Radiat Oncol Biol Phys 1997; 39: 371-380

279 SIGN. SIGN 84: Management of breast cancer in women. Edinburgh (Scotland): SIGN; 2005

280 Slamon DJ, Leyland-Jones B, Shak $S$ et al. Use of chemotherapy plus a monoclonal antibody against HER2 for metastatic breast cancer that overexpresses HER2. [CANADA]. N Engl J Med 2001; 344: 783-792

281 Sledge Jr. GW, Hu P, Falkson G et al. Comparison of chemotherapy with chemohormonal therapy as first-line therapy for metastatic, hormone-sensitive breast cancer: An Eastern Cooperative Oncology Group study. J Clin Oncol 2000; 18: 262-266

282 Smith BD, Bentzen SM, Correa CR et al. Fractionation for whole breast irradiation: an American Society for Radiation Oncology (ASTRO) evidence-based guideline. Int J Radiat Oncol Biol Phys 2011; 81: 59-68

283 Smith BD, Haffty BG, Buchholz TA et al. Effectiveness of radiation therapy in older women with ductal carcinoma in situ. J Natl Cancer Inst 2006; 98: 1302-1310

284 Stadtmauer EA, O'Neill A, Goldstein LJ et al. Conventional-dose chemotherapy compared with high-dose chemotherapy plus autologous hematopoietic stem-cell transplantation for metastatic breast cancer. Philadelphia Bone Marrow Transplant Group. N Engl J Med 2000; 342: 1069-1076 
285 Steenland E, Leer JW, van Houwelingen $H$ et al. The effect of a single fraction compared to multiple fractions on painful bone metastases: a global analysis of the Dutch Bone Metastasis Study. Radiother Oncol 1999; 52: 101-109

286 Stockler $M$, Wilcken $N$, Ghersi $D$ et al. The management of advanced breast cancer: systemic reviews of randomised controlled trials regarding the use of cytotoxic chemotherapy and endocrine therapy. Woolloomooloo 1997; Canberra (Australien): NHMRC

287 Stockler M, Wilcken NR, Ghersi D et al. Systematic reviews of chemotherapy and endocrine therapy in metastatic breast cancer. Cancer Treat Rev 2000; 26: 151-168

288 Stopeck AT, Lipton A, Body JJ et al. Denosumab compared with zoledronic acid for the treatment of bone metastases in patients with advanced breast cancer: a randomized, double-blind study. J Clin Oncol 2010; 28: 5132-5139

289 Taylor CW, Green S, Dalton WS et al. Multicenter randomized clinical trial of goserelin versus surgical ovariectomy in premenopausal patients with receptor-positive metastatic breast cancer: an intergroup study. J Clin Oncol 1998; 16: 994-999

290 The Association of Breast Surgery at BASO RCOSoE. Guidelines for the management of symptomatic breast disease. Eur J Surg Oncol 2005; 31 (Suppl. 1): 1-21

291 Theriault RL, Lipton A, Hortobagyi GN et al. Pamidronate reduces skeletal morbidity in women with advanced breast cancer and lytic bone lesions: a randomized, placebo-controlled trial. Protocol 18 Aredia Breast Cancer Study Group. J Clin Oncol 1999; 17: 846-854

292 Thuerlimann B, Price KN, Castiglione $M$ et al. Randomized controlled trial of ovarian function suppression plus tamoxifen versus the same endocrine therapy plus chemotherapy: Is chemotherapy necessary for premenopausal women with node-positive, endocrine-responsive breast cancer? First results of International Breast Cancer Study Group Trial 11-93. [DKG-R]. Breast 2001; 10 (Suppl. 3): 130-138

293 Tjan-Heijnen VC, de Boer M. Minimal lymph node involvement and outcome of breast cancer. The results of the Dutch MIRROR study. Discov Med 2009; 8: 137-139

294 Torrenga $H$, Fabry $H$, van der Jr. S et al. Omitting axillary lymph node dissection in sentinel node negative breast cancer patients is safe: a long term follow-up analysis. J Surg Oncol 2004; 88: 4-7

295 Truong PT, Olivotto IA, Kader HA et al. Selecting breast cancer patients with T1-T2 tumors and one to three positive axillary nodes at high postmastectomy locoregional recurrence risk for adjuvant radiotherapy. Int J Radiat Oncol Biol Phys 2005; 61: 1337-1347

296 Truong PT, Olivotto IA, Whelan TJ et al. Clinical practice guidelines for the care and treatment of breast cancer: 16 . Locoregional post-mastectomy radiotherapy. CMAJ 2004; 170: 1263-1273

297 Truong PT, Vinh-Hung V, Cserni G et al. The number of positive nodes and the ratio of positive to excised nodes are significant predictors of survival in women with micrometastatic node-positive breast cancer. Eur J Cancer 2008; 44: 1670-1677

298 Tsoutsou PG, Belkacemi Y, Gligorov J et al. Optimal sequence of implied modalities in the adjuvant setting of breast cancer treatment: an update on issues to consider. Oncologist 2010; 15: 1169-1178

299 Turnbull L, Brown S, Harvey I et al. Comparative effectiveness of MRI in breast cancer (COMICE) trial: a randomised controlled trial. Lancet 2010; 375: 563-571

300 UICC. TNM classification of malignant tumours. In: Sobin L, Gospodarowicz M, Wittekind C, eds. 7th ed. New York: Wiley-Liss; 2010

301 Velikova G, Booth $L$, Smith $A B$ et al. Measuring quality of life in routine oncology practice improves communication and patient well-being: a randomized controlled trial. J Clin Oncol 2004; 22: 714-724

302 Velikova G, Wright EP, Smith AB et al. Automated collection of qualityof-life data: a comparison of paper and computer touch-screen questionnaires. J Clin Oncol 1999; 17: 998-1007
303 Veronesi $U$, Cascinelli N, Mariani L et al. Twenty-year follow-up of a randomized study comparing breast-conserving surgery with radical mastectomy for early breast cancer. N Engl J Med 2002; 347: 12271232

304 Veronesi U, Paganelli G, Viale G et al. A randomized comparison of sentinel-node biopsy with routine axillary dissection in breast cancer. $\mathrm{N}$ Engl J Med 2003; 349: 546-553

305 Vogel C, O'Rourke M, Winer E et al. Vinorelbine as first-line chemotherapy for advanced breast cancer in women 60 years of age or older. Ann Oncol 1999; 10: 397-402

306 Vogl TJ, Muller PK, Mack MG et al. Liver metastases: interventional therapeutic techniques and results, state of the art. Eur Radiol 1999; 9: 675-684

307 von Minckwitz G, Kaufmann M, Möhrle D et al. Hormonelle Folgetherapien nach Goserelin (Zoladex ${ }^{\circledR}$ ) beim metastasierten Mammakarzinom prämenopausaler Patientinnen. [AGO]. Arch Gynecol Obst 1991; 250: $258-260$

308 von Minckwitz G, Untch M, Nuesch E et al. Impact of treatment characteristics on response of different breast cancer phenotypes: pooled analysis of the German neo-adjuvant chemotherapy trials. Breast Cancer Res Treat 2011; 125: 145-156

309 Voogd AC, Nielsen M, Peterse JL et al. Differences in risk factors for local and distant recurrence after breast-conserving therapy or mastectomy for stage I and II breast cancer: pooled results of two large European randomized trials. J Clin Oncol 2001; 19: 1688-1697

310 Voordeckers M, Vinh-Hung V, Lamote J et al. Survival benefit with radiation therapy in node-positive breast carcinoma patients. Strahlenther Onkol 2009; 185: 656-662

311 Voskuil DW, van Nes JG, Junggeburt JM et al. Maintenance of physical activity and body weight in relation to subsequent quality of life in postmenopausal breast cancer patients. Ann Oncol 2010; 21: 20942101

312 Wald NJ, Murphy P, Major P et al. UKCCCR multicentre randomised controlled trial of one and two view mammography in breast cancer screening. BMJ 1995; 311: 1189-1193

313 Walker MP, Yaszemski MJ, Kim CW et al. Metastatic disease of the spine: evaluation and treatment. Clin Orthop Relat Res 2003; 415: S165-S175

314 Weaver DL, Krag DN, Ashikaga T et al. Pathologic analysis of sentinel and nonsentinel lymph nodes in breast carcinoma: a multicenter study. Cancer 2000; 88: 1099-1107

315 Whelan T, Clark R, Roberts $R$ et al. Ipsilateral breast tumor recurrence postlumpectomy is predictive of subsequent mortality: results from a randomized trial. Investigators of the Ontario Clinical Oncology Group. Int J Radiat Oncol Biol Phys 1994; 30: 11-16

316 Whelan T, Darby S, Taylor C et al. Overviews of randomized trials of radiotherapy in early breast cancer. ASCO's Annual Meeting Educational Book. Chicago (USA): ASCO; 2007: 3-6

317 Whelan T, Levine M. Radiation therapy and tamoxifen: concurrent or sequential? That is the question. J Clin Oncol 2005; 23: 1-4

318 Whelan TJ, Pignol JP, Levine MN et al. Long-term results of hypofractionated radiation therapy for breast cancer. N Engl J Med 2010; 362: 513-520

319 WHO. World Health Organization Classification of Tumours. Pathology and Genetics of Tumours of the Breast and female Genital Organs. In: Tavassoli FA, Devilee P, eds. Lyon: IARC Press; 2003: 9-112

320 Wolff AC, Hammond ME, Schwartz JN et al. American Society of Clinical Oncology/College of American Pathologists guideline recommendations for human epidermal growth factor receptor 2 testing in breast cancer. J Clin Oncol 2007; 25: 118-145

321 Wunder JS, Ferguson PC, Griffin AM et al. Acetabular metastases: planning for reconstruction and review of results. Clin Orthop Relat Res 2003; 415: S187-S197 